\title{
Peripheral and Axial Substitution of Phthalocyanines with Solketal Groups: Synthesis and In Vitro Evaluation for Photodynamic Therapy
}

\author{
Jan-Willem Hofman, ${ }^{\dagger}$ Femke van Zeeland, ${ }^{\dagger}$ Selcan Turker, ${ }^{\dagger}$ Herre Talsma, ${ }^{\dagger}$ Saskia A. G. Lambrechts, ${ }^{\dagger}$ Dmitri V. Sakharov ${ }^{\ddagger}$
} Wim E. Hennink, ${ }^{\dagger}$ and Cornelus F. van Nostrum*,†

Department of Pharmaceutics, Utrecht Institute of Pharmaceutical Sciences (UIPS), Utrecht University, Post Office Box 80082, 3508 TB Utrecht, The Netherlands, and Department of Biochemistry of Lipids, CBLE, Utrecht University, Post Office Box 80054, 3508 TB Utrecht, The Netherlands

Received September 29, 2006

Phthalocyanines (Pcs) are a class of photosensitizers (PSs) with a strong tendency to aggregate in aqueous environment, which has a negative influence on their photosensitizing ability in photodynamic therapy. Pcs with either peripheral or axial solketal substituents, that is, $\mathrm{ZnPc}(\mathrm{sol})_{8}$ and $\mathrm{Si}(\mathrm{sol})_{2} P c$, respectively, were synthesized and their tendency to aggregate as well as their photodynamic properties in 14C and B16F10 cell lines were evaluated. The results were compared to more hydrophilic silicon Pcs, that is, $\mathrm{Si}(\mathrm{PEG} 750)_{2} \mathrm{Pc}$ and Pc4. The order of cellular uptake was $\mathrm{Pc} 4>\mathrm{ZnPc}(\mathrm{sol})_{8}>\mathrm{Si}(\mathrm{PEG} 750)_{2} \mathrm{Pc}>\mathrm{Si}\left(\mathrm{sol}_{2}\right) \mathrm{Pc}$. In contrast, $\mathrm{Si}\left(\mathrm{Sol}_{2}\right) \mathrm{Pc}$ showed the highest photocytotoxicity, while $\mathrm{ZnPc}(\mathrm{sol})_{8}$ did not show any photocytotoxicity up to a concentration of $10 \mu \mathrm{M}$ in both cell types. UV/vis spectroscopy showed that $\mathrm{Si}(\mathrm{sol})_{2} \mathrm{Pc}$ is less prone to aggregation than $\mathrm{ZnPc}(\mathrm{sol})_{8}$, which can explain the lack of photoactivity of the latter. $\mathrm{Si}(\mathrm{sol})_{2} \mathrm{Pc}$ was predominantly located in lipid droplets, whereas $\mathrm{Si}(\mathrm{PEG} 750)_{2} \mathrm{Pc}$ was homogeneously distributed in the cytosol, which is probably the main cause of their difference in photoactivity. The very high photodynamic efficacy of $\mathrm{Si}(\mathrm{sol})_{2} \mathrm{Pc}$ makes this PS an interesting candidate for future studies.

\section{Introduction}

Photodynamic therapy (PDT) is an attractive modality for the treatment of cancer. ${ }^{1}$ It involves the illumination of a photosensitive compound with light of an appropriate wavelength, that is, in the range of $630-800 \mathrm{~nm}$ for which tissue penetration is optimal. ${ }^{2}$ By directing the light beam to the target area, PDT can be used to selectively destroy cancer tissue without harming surrounding cells. The light-activated photosensitizer (PS) can form reactive oxygen species (ROS) via either a so-called type I reaction or by direct reaction with molecular oxygen by a so-called type II reaction to form highly active singlet oxygen. ${ }^{2}$ ROS are oxidizing agents that react with cellular components, such as unsaturated lipids, RNA/DNA, or side chains of certain amino acids, like cystein, methionine, tyrosine, histidine, and tryptophan. ${ }^{3,4}$ These oxidative effects ultimately result in cell death. Singlet oxygen is generally excepted as the main species responsible for the observed photodynamic effect. ${ }^{5}$

Porfimer sodium (Photofrin), a complex mixture of hematoporphyrin derivatives, was the first clinically approved PS for photodynamic treatment of bladder cancer in 1993 in Canada. ${ }^{1,6}$ Although encouraging results have been obtained, it has some serious limitations. The molecular absorption coefficient of porfimer sodium at the clinically used wavelength of $630 \mathrm{~nm}$ is low $\left(\epsilon=1170 \mathrm{l} \cdot \mathrm{mol}^{-1} \cdot \mathrm{cm}^{-1}\right){ }^{6}$ More importantly, it causes skin photosensitivity for a prolonged period of time, up to 3090 days after treatment, due to its accumulation and retention in skin tissues. ${ }^{7}$ Therefore, much research has been devoted to developing new photosensitive compounds with improved photophysical efficiency and fewer side effects. To achieve optimal efficacy, a PS should meet several requirements, ${ }^{4-6,8}$

* To whom correspondence should be addressed. Phone: +31(0)302537306. Fax: +31(0)30-2517839. E-mail: c.f.vannostrum@pharm.uu.nl.

Department of Pharmaceutics.

$\doteqdot$ Department of Biochemistry of Lipids.
Chart 1. Structural Formula of Pc4

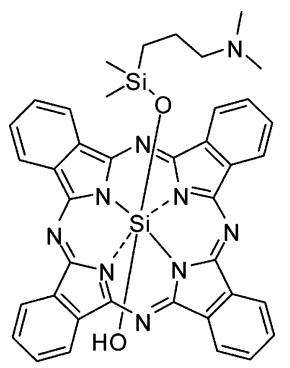

including (i) high absorbance at wavelengths $>600 \mathrm{~nm}$, (ii) low tendency to aggregate intracellularly to achieve a maximal yield of singlet oxygen, and (iii) favorable intracellular localization properties, for example, in mitochondrial membranes, ${ }^{4,9}$ because the diffusion range of singlet oxygen is small. Phthalocyanines (Pcs) are very well suited to be used as PSs for PDT due to their high molecular absorption coefficients at higher wavelengths of the visible spectrum $\left(\epsilon \approx 10^{5} 1 \cdot \mathrm{mol}^{-1} \cdot \mathrm{cm}^{-1}\right.$ at $640-$ $710 \mathrm{~nm}$ ), lack of dark toxicity, and chemical stability. Pcs used for PDT include the zinc-phthalocyanine ( $\mathrm{ZnPc}),{ }^{10}$ aluminumphthalocyanine (AlPc), ${ }^{11,12}$ and silicon-phthalocyanine $(\mathrm{SiPc})^{13,14}$ derivatives. However, these compounds often show aggregation in aqueous media and have unfavorable intracellular localization. To prevent stacking of the hydrophobic Pc core and intracellular aggregation, those compounds can be substituted with bulky or charged groups at the periphery of the Pc ring. ${ }^{15-17}$ Furthermore, incorporation of a tri- or tetravalent metal atom in the Pc core, like aluminum(III) or silicon(IV), enables axial derivatization, which can affect the solubility in aqueous media even more by improved steric shielding of the Pc core. ${ }^{12,14,18} \mathrm{Pc} 4{ }^{19-22}$ (Chart $1)$, an axially substituted Pc that localizes intracellularly in mitochondria, is known as one of the most potent Pc-based PSs and has been used in clinical trials. ${ }^{23}$

No studies to date have been directed to the comparison of Pcs substituted with the same groups either on the axial or 
Scheme 1. Synthesis Route to the Peripherally Substituted $\mathrm{ZnPc}(\mathrm{sol})_{8}$
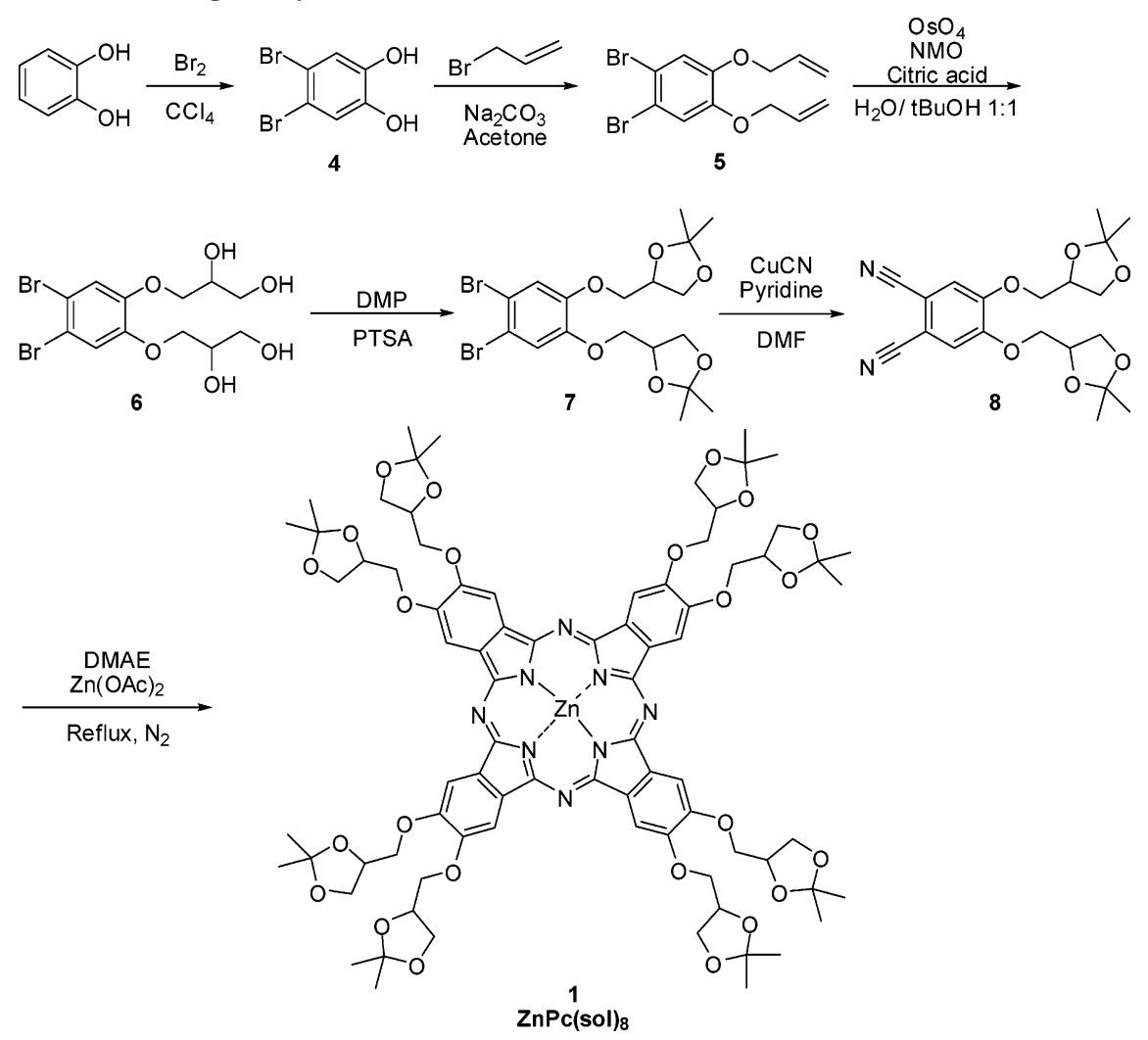

Scheme 2. Synthesis Route to the Axially Substituted $\mathrm{Si}(\mathrm{sol})_{2} \mathrm{Pc}$ and $\mathrm{Si}(\mathrm{PEG} 750)_{2} \mathrm{Pc}$

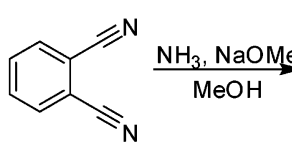

Phthalonitril

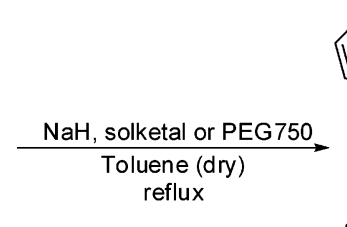

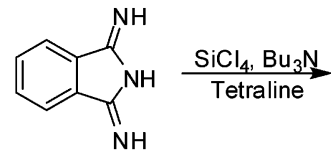

9

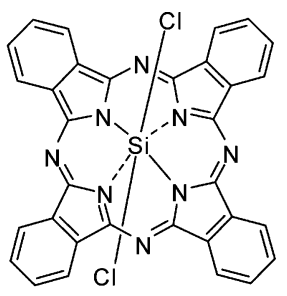

$\mathrm{Si}(\mathrm{Cl})_{2} \mathrm{Pc}$

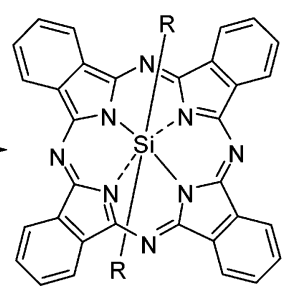

2, $\mathrm{Si}(\mathrm{sol})_{2} \mathrm{Pc}: \mathrm{R}=$<smiles>CC1(C)OCC(CO)O1</smiles>

$3, \mathrm{Si}(\mathrm{PEG} 750)_{2} \mathrm{PC}: \mathrm{R}=$ of $\mathrm{O}$.

peripheral positions. In this study, two Pcs either peripherally or axially substituted with solketal groups were synthesized, that is, $\mathrm{ZnPc}(\mathrm{sol})_{8}(\mathbf{1})$ and $\mathrm{Si}(\mathrm{sol})_{2} \mathrm{Pc}(\mathbf{2})$, respectively (Schemes 1 and 2). Solketal, which is a hydrophobic unit that can be converted, in vivo, by acid-catalyzed hydrolysis to form hydrophilic glyceryl, ${ }^{24}$ was chosen with the aim to combine the favorable tumor uptake of hydrophobic PSs with the expected rapid clearance, for example, from the skin, once converted to the hydrophilic counterpart. In this study, the cellular uptake, intracellular localization, and overall photodynamic efficacy of the two hydrophobic Pc derivatives were investigated and compared with two hydrophilic SiPcs, that is, $\mathrm{Si}(\mathrm{PEG} 750)_{2} \mathrm{Pc}$ (3), containing polyethylene glycol (PEG) chains, and Pc4.

\section{Results}

Synthesis. The peripherally substituted $\mathrm{ZnPc}(\mathrm{sol})_{8}$ was synthesized according to Scheme 1, starting from catechol, which was first brominated using elemental bromine in tetrachloromethane. ${ }^{25}$ The product (4) was used without further purification for the reaction with allylbromide to form $\mathbf{5}$. This compound was isolated as a crystalline solid or as an oil, which solidified in a few hours. Next, the allyl groups were dihydroxylated using osmium tetraoxide as a catalyst in a tertbutanol/water (1:1) mixture. This reaction was done in the presence of 4-methylmorpholine-4-oxide, to regenerate the catalyst, and citric acid, as suggested by Dupau et al. ${ }^{26}$ Citric acid was added as $\mathrm{pH}$ modifier, and it was hypothesized that it can also act as a ligand for osmium, stabilizing the catalytically active Os(IV) species in solution against disproportionation to Os(VIII) and insoluble Os(IV) species.

The bis(dihydroxylated) product (6) was formed in an excellent yield (95\%), with a high purity ( $>99 \%)$, as was established by NMR and HPLC. The OH groups of $\mathbf{6}$ were reacted with 2,2-dimethoxypropane (DMP) to form 7 . Nitrile 


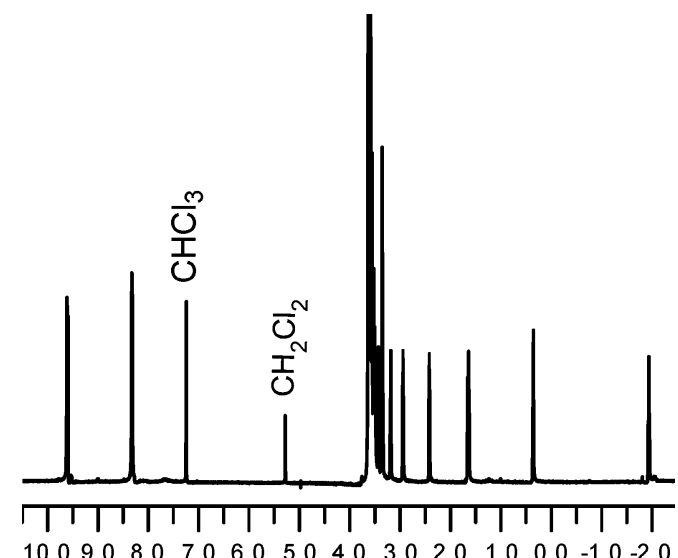

Figure 1. ${ }^{1} \mathrm{H} \mathrm{NMR}$ of $\mathrm{Si}(\mathrm{PEG} 750)_{2} \mathrm{Pc}$ in $\mathrm{CDCl}_{3}$. Methylene groups of the PEG chain closest to the Pc ring have the higest upfield shift. See Experimental Section for assignment of the peaks.

groups were introduced, according to the Rosenmund-von Braun reaction, by substitution of the bromine groups of 7 with $\mathrm{CuCN}$ in DMF, which yielded phthalonitrile derivative 8 in a reasonable yield (59\%). The 2,3,9,10,16,17,23,24-octasolketalsubstituted $\mathrm{Pc} \mathrm{ZnPc}(\mathrm{sol})_{8}$ (1) was formed in a cyclotetramerization reaction of $\mathbf{8}$ in dimethylethanolamine as solvent in the presence of $\mathrm{Zn}(\mathrm{OAc})_{2}$. The crude product was purified by flash chromatography with gradient elution using a mixture of EtOAc and hexane as eluents. Shifting the eluent from EtOAc/hexane (2:1) to EtOAc after removal of side products caused the elution of the product. The overall yield starting from catechol was $31 \%$.

$\mathrm{Si}(\mathrm{Cl})_{2} \mathrm{Pc}$ was synthesized starting from phthalonitril (Scheme $2)$, which was allowed to react with ammonia to form 1,3diiminoisoindoline (9), according to Sasa et al. ${ }^{27} \mathrm{Si}(\mathrm{Cl})_{2} \mathrm{Pc}$ was formed by reaction of $\mathbf{9}$ with $\mathrm{SiCl}_{4}$ in tetraline, according to Davison et al., ${ }^{28}$ in a yield of $70 \%$. The identity of the product was confirmed by comparison of its FTIR spectrum with that of the commercial-derived product (Sigma). $\mathrm{Si}(\mathrm{sol})_{2} \mathrm{Pc}(2)$ was synthesized by substitution of $\mathrm{Si}(\mathrm{Cl})_{2} \mathrm{Pc}$ with solketal in toluene.

$\mathrm{Si}(\mathrm{PEG} 750)_{2} \mathrm{Pc}(3)$ was synthesized according to Huang et al., ${ }^{29}$ that is, $\mathrm{Si}(\mathrm{Cl})_{2} \mathrm{Pc}$ was reacted with monomethoxy $\mathrm{PEG}_{750}$ and $\mathrm{NaH}$ in toluene. However, work up of the product by extraction with $\mathrm{H}_{2} \mathrm{O} / \mathrm{EtOAc}$, to remove excess of free $\mathrm{PEG}$, was not effective in our hands. After extensive purification with flash chromatography, the product was obtained as a blue paste.

Characterization. The synthesized Pcs had high purity (>97\%) according to NMR, HPLC, and elemental analysis. The PEGylated Pc had a good solubility in water $(>5 \mathrm{mg} / \mathrm{mL})$, whereas $\mathrm{ZnPc}(\mathrm{sol})_{8}$ and $\mathrm{Si}(\mathrm{sol})_{2} \mathrm{Pc}$ did not show detectable dissolution in water. ${ }^{1} \mathrm{H} \mathrm{NMR}$ spectra recorded in $\mathrm{CDCl}_{3}$ clearly showed the shielding of the substituent protons by the electron cloud of the Pc ring in the axially substituted SiPcs, that is, $\mathrm{Si}(\mathrm{sol})_{2} \mathrm{Pc}$ and $\mathrm{Si}(\mathrm{PEG} 750)_{2} \mathrm{Pc}$. The closer the atoms of the axial substituents are to the point of attachment to the Pc ring, the larger the upfield shift of the group. For $\mathrm{Si}(\mathrm{PEG} 750)_{2} \mathrm{Pc}$, this effect was visible from the closest methylene group $(\delta-1.95$ ppm) up to nine methylene units away (Figure 1), which was in agreement with previously reported data for this compound. ${ }^{29,30}$ The same phenomenon was also observed for the solketal substituents of $\mathrm{Si}(\mathrm{sol})_{2} \mathrm{Pc}$, where the methylene unit closest to the ring had a shift of $-2.0 \mathrm{ppm}$. The ${ }^{1} \mathrm{H}$ NMR spectrum of $\mathrm{ZnPc}(\mathrm{sol})_{8}$ in $\mathrm{CDCl}_{3}$ showed very broad and unresolved peaks, as was also shown by Kimura et al. ${ }^{31}$ Furthermore, the signals from the aromatic Pc ring were missing in the ${ }^{13} \mathrm{C}$ NMR spectrum. However, when DMSO- $d_{6}$ was used

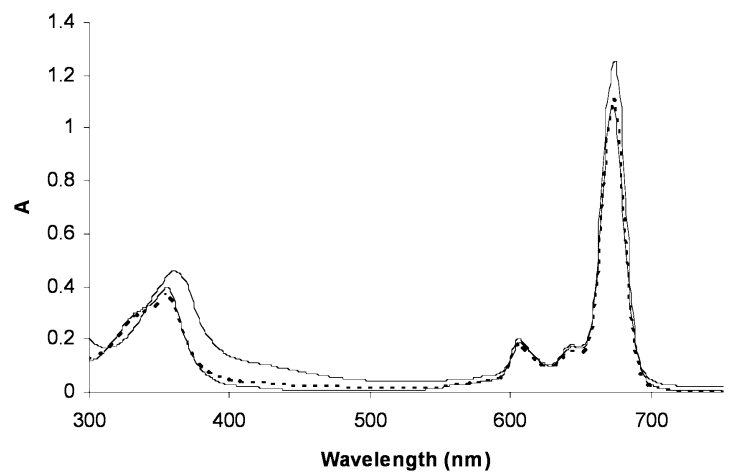

Figure 2. UV-vis spectra of $\mathrm{Si}(\mathrm{sol})_{2} \mathrm{Pc}(-), \mathrm{ZnPc}(\mathrm{sol})_{8}(---)$, and $\mathrm{Si}(\mathrm{PEG} 750)_{2} \mathrm{Pc}(\ldots), 5 \mu \mathrm{M}$ in DMF.

as solvent, good resolution was obtained in the ${ }^{1} \mathrm{H}$ NMR spectrum and the core signals were visible in the ${ }^{13} \mathrm{C}$ NMR spectrum. $\mathrm{ZnPc}(\mathrm{sol})_{8}$ is probably aggregated in $\mathrm{CDCl}_{3}$, yielding a colloidal solution, at the concentrations used for the NMR measurements, whereas in DMSO- $d_{6}$, it is molecularly dissolved.

$\mathrm{UV} / \mathrm{vis}$ spectroscopy was used to investigate in more detail the aggregation behavior of $\mathrm{Si}(\mathrm{sol})_{2} \mathrm{Pc}$ and $\mathrm{ZnPc}(\mathrm{sol})_{8}$ at relevant concentrations ( $\mu \mathrm{M}$ range). Aggregation was induced by titration of a solution of PS in DMF with $\mathrm{H}_{2} \mathrm{O}$. The absorption spectra of $\mathrm{ZnPc}(\mathrm{sol})_{8}, \mathrm{Si}(\mathrm{sol})_{2} \mathrm{Pc}$, and $\mathrm{Si}(\mathrm{PEG} 750)_{2} \mathrm{Pc}$ in DMF showed a B (or Soret) band at 330-370 $\mathrm{nm}$ and a strong absorption peak (Q-band) at $674 \mathrm{~nm}$ (Figure 2), together with two vibrational bands at 603 and $639 \mathrm{~nm}$, characteristic of nonaggregated Pcs. The change in the absorbance of the Q-band in the UV-vis spectrum upon addition of water was recorded and plotted against the dielectric constant of the solvent mixture (see Figure 3). Figure 3c shows that the critical dielectric constant of the solvent mixture above which aggregation occurred is $\sim 45$ and 58 for $\mathrm{ZnPc}(\mathrm{sol})_{8}$ and $\mathrm{Si}(\mathrm{sol})_{2} \mathrm{Pc}$, respectively. This demonstrates that, as anticipated, axially substituted $\mathrm{Si}(\mathrm{sol})_{2} \mathrm{Pc}$ has a lower tendency for stacking and aggregation than the peripherally substituted $\mathrm{ZnPc}(\mathrm{sol})_{8}$.

Photocytotoxicity. The concentration-dependent phototoxicity of $\mathrm{ZnPc}(\mathrm{sol})_{8}, \mathrm{Si}(\mathrm{sol})_{2} \mathrm{Pc}$, and $\mathrm{Si}(\mathrm{PEG} 750)_{2} \mathrm{Pc}$ toward B16F10 and 14C cells was determined after $6 \mathrm{~h}$ of incubation and subsequent illumination with a light intensity of 3.5 $\mathrm{mW} \cdot \mathrm{cm}^{-2}$ for $10 \mathrm{~min}$ (Figure 4 ). Under these conditions, the light dose was $2.1 \mathrm{~J} \cdot \mathrm{cm}^{-2}$. None of the PSs showed dark cytotoxicity (Figure 4). $\mathrm{ZnPc}(\mathrm{sol})_{8}$ did not show photocytotoxicity up to the highest concentration used $(10 \mu \mathrm{M}$, not shown in the figure). The $\mathrm{IC}_{50}$ values (i.e., concentration of PS added to the medium during incubation, at which illumination resulted in 50\% cell death) of the other PSs are reported in Table 1, together with the values of $\mathrm{Pc} 4$. $\mathrm{Si}(\mathrm{sol})_{2} \mathrm{Pc}$ is approximately 1 order of magnitude more effective than $\mathrm{Si}(\mathrm{PEG} 750)_{2} \mathrm{Pc}$ and two to three times more effective than Pc4 in both cell lines.

Cellular Uptake. The uptake of $\mathrm{ZnPc}(\mathrm{sol})_{8}, \mathrm{Si}(\mathrm{sol})_{2} \mathrm{Pc}, \mathrm{Si}-$ (PEG750) 2 Pc, and Pc4 by B16F10 and 14C cells was investigated. The amount of PS that was taken up was determined by fluorescence spectrometry after cell lysis and expressed relative to the cellular protein amount (Table 1). For both cell lines, the amount of $\mathrm{ZnPc}(\mathrm{sol})_{8}$ taken up was about ten times higher than for $\mathrm{Si}(\mathrm{sol})_{2} \mathrm{Pc}$ and $\mathrm{Si}(\mathrm{PEG} 750)_{2} \mathrm{Pc}$. Table 1 also shows that the uptake of Pc4 was about 20 times higher than for $\mathrm{Si}(\mathrm{sol})_{2} \mathrm{Pc}$ and $\mathrm{Si}(\mathrm{PEG} 750)_{2} \mathrm{Pc}$. To establish whether an energy-dependent process is responsible for the uptake of $\mathrm{Si}(\mathrm{sol})_{2} \mathrm{Pc}, \mathrm{ZnPc}(\mathrm{sol})_{8}$, and $\mathrm{Si}(\mathrm{PEG} 750)_{2} \mathrm{Pc}$ by B16F10 cells, the same experiments were carried out at $4{ }^{\circ} \mathrm{C}$. At this temperature, energy-dependent processes are inhibited and compounds can penetrate into the 
(a)

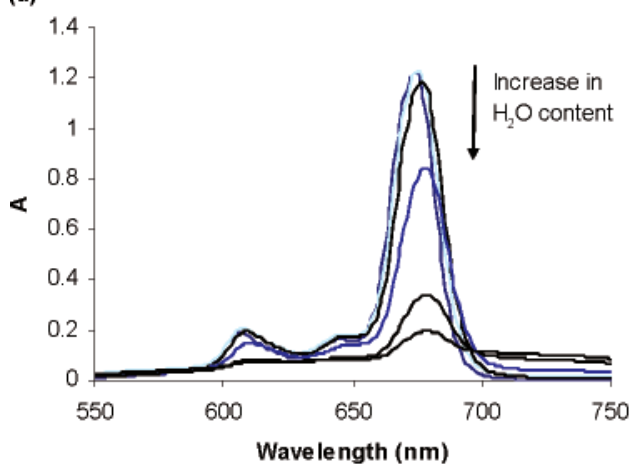

(b)

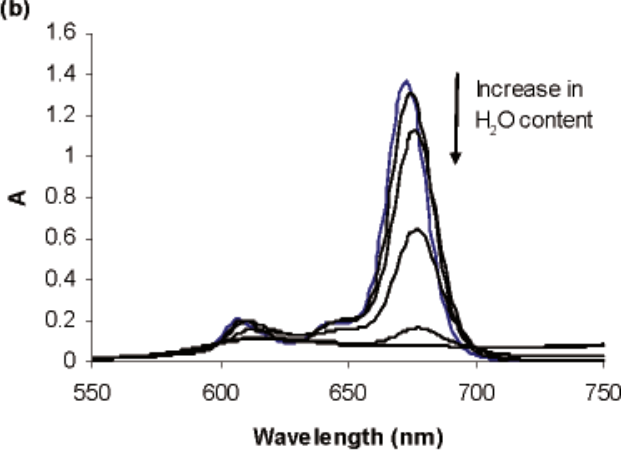

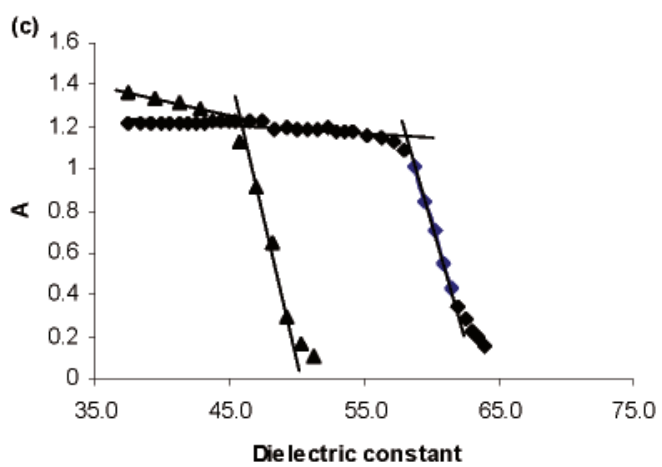

Figure 3. Selected absorption spectra of $\mathrm{Si}(\mathrm{sol})_{2} \mathrm{Pc}$ (a) and $\mathrm{ZnPc}(\mathrm{sol})_{8}$ (b) upon titration of a PS solution $(5 \mu \mathrm{M})$ in $\mathrm{DMF}$ with $\mathrm{H}_{2} \mathrm{O}$. (c) $\mathrm{Decrease}$ of $A_{\max }$ of the Q-band of $\mathrm{Si}(\mathrm{sol})_{2} \mathrm{Pc}$ (squares) and $\mathrm{ZnPc}(\mathrm{sol})_{8}$ (triangles) as a function of the dielectric constant of the solvent mixture. The absorbances were corrected for the shift in concentration due to addition of $\mathrm{H}_{2} \mathrm{O}$.
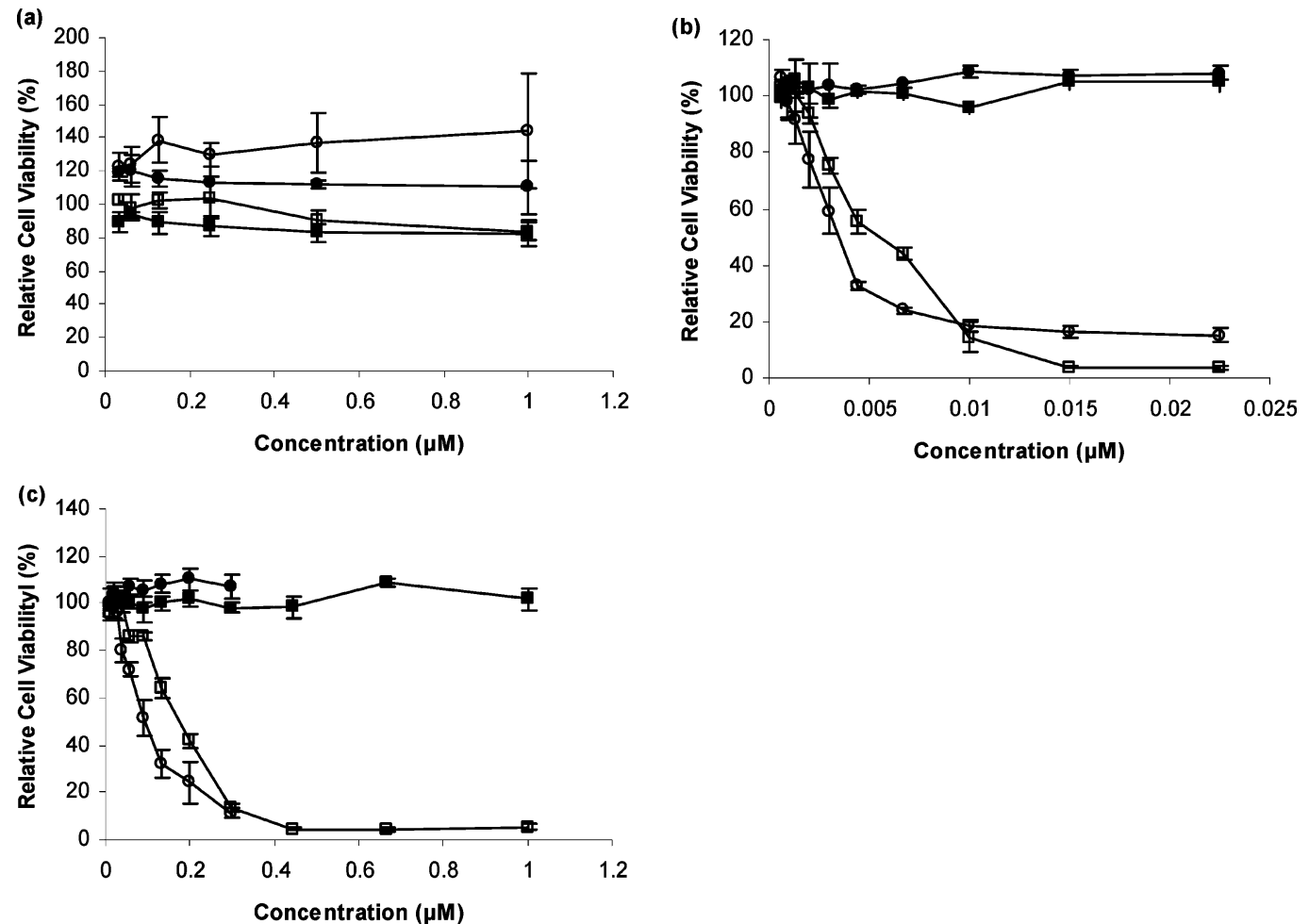

Figure 4. Relative cell viability after $6 \mathrm{~h}$ of incubation with PS at various concentrations in the medium, followed by illumination for 10 min with $3.5 \mathrm{~mW}$ (open symbols) and without illumination (closed symbols) of (a) $\mathrm{ZnPc}(\mathrm{sol})_{8}$, (b) $\mathrm{Si}(\mathrm{sol})_{2} \mathrm{Pc}$, and (c) $\mathrm{Si}(\mathrm{PEG} 750)_{2} \mathrm{Pc}$ toward B16F10 cells (squares) and 14C cells (circles). Values are expressed as the average of three experiments \pm SEM $(n=3)$.

cells only by passive diffusion. For $\mathrm{Si}(\mathrm{sol})_{2} \mathrm{Pc}$ and $\mathrm{ZnPc}(\operatorname{sol})_{8}$, no significant differences in uptake were found between the experiment run at $4{ }^{\circ} \mathrm{C}$ and the experiment run at $37{ }^{\circ} \mathrm{C}$. The cellular uptake of $\mathrm{Si}(\mathrm{PEG} 750)_{2} \mathrm{Pc}$ at $4{ }^{\circ} \mathrm{C}$ was $\sim 3$ times lower than the uptake at $37^{\circ} \mathrm{C}$.
Intracellular Localization. Confocal fluorescence microscopy was used to examine qualitatively the distribution kinetics and intracellular localization of $\mathrm{ZnPc}(\mathrm{sol})_{8}, \mathrm{Si}(\mathrm{PEG} 750)_{2}$, and $\mathrm{Si}(\mathrm{sol})_{2} \mathrm{Pc}$ in both $\mathrm{B} 16 \mathrm{~F} 10$ and $14 \mathrm{C}$ cells. The cells were incubated with $1 \mu \mathrm{M}$ solutions of the PSs for $6 \mathrm{~h}$, and the 
Table 1. Photocytotoxicity and Cell Uptake of Four PSs for B16F10 and $14 \mathrm{C}$ Cells

\begin{tabular}{|c|c|c|c|c|}
\hline \multirow[b]{2}{*}{ sensitizer } & \multicolumn{2}{|c|}{ cell uptake ${ }^{a}$ (nmol/mg protein) } & \multicolumn{2}{|c|}{$\mathrm{IC}_{50}^{b}(\mu \mathrm{M})$} \\
\hline & $\mathrm{B} 16 \mathrm{~F} 10$ & $14 \mathrm{C}$ & B $16 \mathrm{~F} 10$ & $14 \mathrm{C}$ \\
\hline $\mathrm{ZnPc}(\mathrm{sol})_{8}$ & $12.5 \pm 1.0$ & $10.6 \pm 0.3$ & n.a. ${ }^{c}$ & n.a. ${ }^{c}$ \\
\hline $\mathrm{Si}(\mathrm{sol})_{2} \mathrm{Pc}$ & $0.66 \pm 0.11$ & $0.88 \pm 0.19$ & 0.006 & 0.003 \\
\hline $\mathrm{Si}(\mathrm{PEG} 750)_{2} \mathrm{Pc}$ & $0.94 \pm 0.10$ & $1.17 \pm 0.03$ & 0.17 & 0.09 \\
\hline $\mathrm{Pc} 4$ & $17.8 \pm 1.5$ & n.d. & 0.019 & 0.006 \\
\hline
\end{tabular}

${ }^{a}$ Cells were incubated with PS $(10 \mu \mathrm{M})$ for $6 \mathrm{~h}$. The dye content was analyzed as described under Experimental Section. Values are \pm SEM ( $=3$ ). ${ }^{b}$ The $\mathrm{IC}_{50}$ is the concentration of PS added to the medium during 6 $\mathrm{h}$ of incubation, at which subsequent illumination (10 $\mathrm{min}, 3.5 \mathrm{~mW})$ resulted in $50 \%$ reduced cell viability relative to cells without PS added. ${ }^{c}$ Cells did not show any reduced viability after illumination up to the highest concentration tested $(10 \mu \mathrm{M})$

fluorescence was examined at different time points. After $6 \mathrm{~h}$, the incubation medium was removed, and the cells were washed twice with PBS and again visualized after illumination of the cells $\left(10 \mathrm{~min}, 3.5 \mathrm{~mW} / \mathrm{cm}^{2}\right)$. Cells incubated with $\mathrm{ZnPc}(\mathrm{sol})_{8}$, at concentrations up to $10 \mu \mathrm{M}$, showed no intracellular fluorescence. For $\mathrm{Si}(\mathrm{PEG} 750)_{2} \mathrm{Pc}$, a more or less homogeneous distribution in the cytosol of both cell types was observed (Figure 5a). Illumination did not result in a detectable different intracellular distribution. $\mathrm{Si}(\mathrm{sol})_{2} \mathrm{Pc}$ showed a different distribution pattern in both cell types as compared to $\mathrm{Si}(\mathrm{PEG} 750)_{2} \mathrm{Pc}$, that is, fluorescence was mainly observed in spots (most clearly visible in $14 \mathrm{C}$ cells; Figure 5b). The fluorescence intensity of these spots increased in time during incubation. Illumination after $6 \mathrm{~h}$ of incubation caused an increased intensity of the fluorescence and a more homogeneous distribution pattern (Figure 5c), indicating redistribution of the PS in the cells. To investigate the identity of the spots observed in the $\mathrm{Si}(\mathrm{sol})_{2} \mathrm{Pc}$ treated cells, the cells were also incubated with several fluorescent dyes to stain different organelles, that is, mitochondria, lysosomes, endosomes, and lipid droplets. No colocalization of $\mathrm{Si}(\mathrm{sol})_{2} \mathrm{Pc}$ and the fluorescent dye was observed for MitoTracker green, LysoTracker green, and FITC-dextran, suggesting that the PS did not localize in mitochondria, lysosomes, and endosomes, respectively (Figure 5d-f). However, when $\mathrm{B} 16 \mathrm{~F} 10$ or $14 \mathrm{C}$ cells, preincubated with $\mathrm{Si}(\mathrm{sol})_{2} \mathrm{Pc}$,
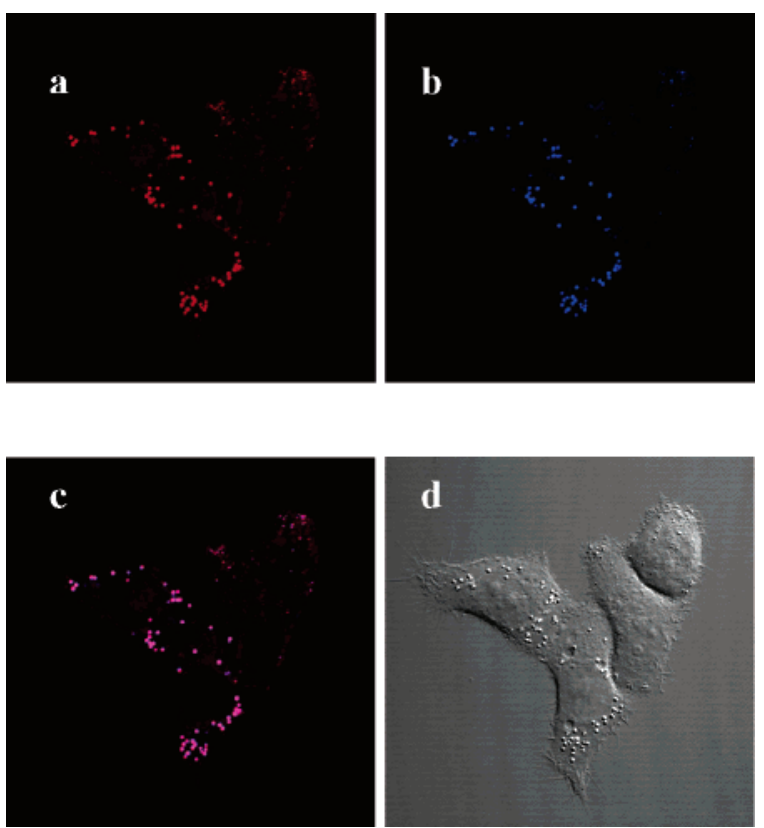

Figure 6. Colocalization of $\mathrm{Si}(\mathrm{sol})_{2} \mathrm{Pc}$ and nile red in $14 \mathrm{C}$ cells after $6 \mathrm{~h}$ of incubation with PS $(1 \mu \mathrm{M})$ : (a) nile red fluorescence; (b) fluorescence of $\mathrm{Si}(\mathrm{sol})_{2} \mathrm{Pc}$; (c) overlay of nile red and $\mathrm{Si}(\mathrm{sol})_{2} \mathrm{Pc}$ fluorescence; and (d) DIC photo of the cells.

were stained with nile red, colocalization of the PS and the dye was observed (Figure $6 \mathrm{a}-\mathrm{c}$ ). The spots were also observed in differential interference contrast (DIC) mode (Figure 6d). Greenspan et al. ${ }^{32}$ showed that nile red preferentially stains lipid droplets in cells. Therefore, colocalization of $\mathrm{Si}(\mathrm{sol})_{2} \mathrm{Pc}$ with the dye indicates that the PS is primarily localized in these hydrophobic organelles and redistributes upon illumination.

\section{Discussion}

The lack of water solubility of $\mathrm{ZnPc}(\mathrm{sol})_{8}$ and $\mathrm{Si}(\mathrm{sol})_{2} \mathrm{Pc}$ emphasizes the hydrophobicity of these compounds. In contrast, the hydrophilic PEG chains of $\mathrm{Si}(\mathrm{PEG} 750)_{2} \mathrm{Pc}$ are very effective in shielding the hydrophobic Pc core, making the PS much more
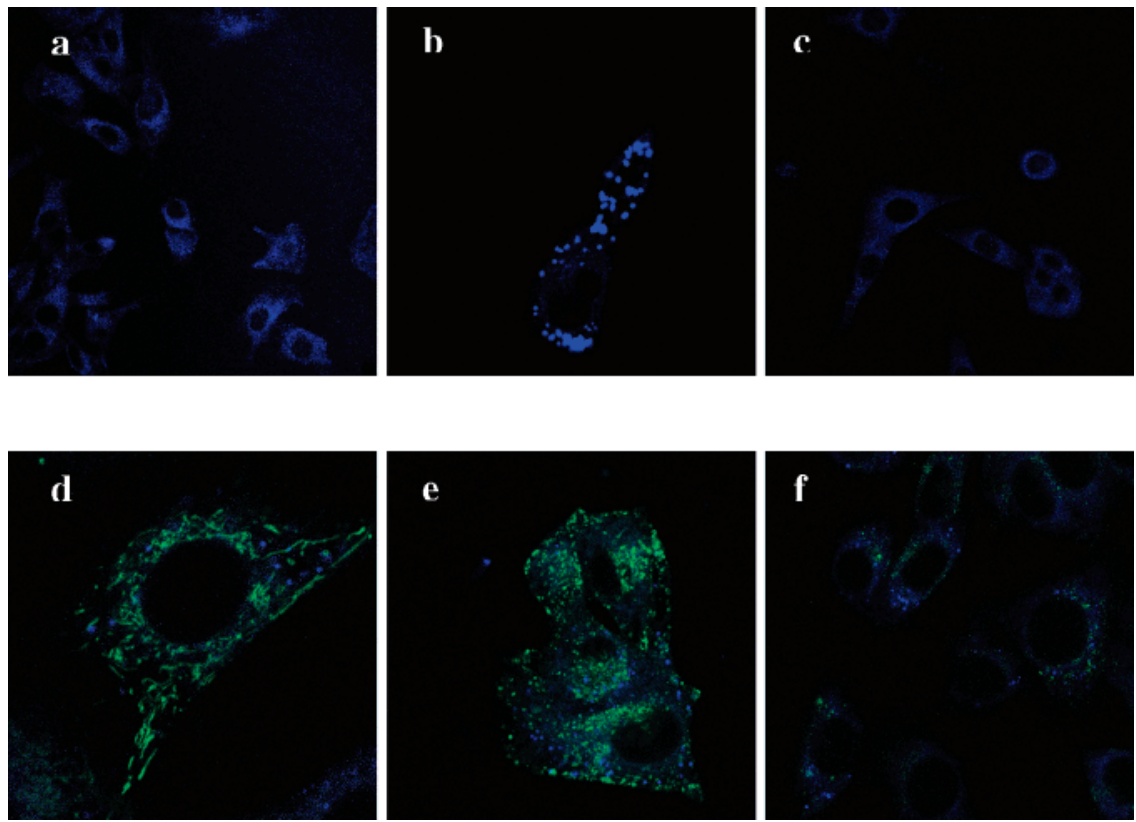

Figure 5. Intracellular localization of $\mathrm{Si}(\mathrm{PEG} 750)_{2} \mathrm{Pc}(\mathrm{a})$ and $\mathrm{Si}(\mathrm{sol})_{2} \mathrm{Pc}(\mathrm{b}-\mathrm{f})$ in $14 \mathrm{C}$ cells after $6 \mathrm{~h}$ of incubation with $1 \mu \mathrm{M}$ PS: (c) illuminated after incubation; (d) incubated with MitoTracker green; (e) incubated with LysoTracker green; and (f) incubated with FITC-dextran. PSs and dyes are presented in blue and green, respectively. 
hydrophilic and highly soluble in water. Aggregation, due to $\pi-\pi$ stacking of the aromatic Pc rings, is frequently observed for Pcs. ${ }^{25,33}$ Singlet oxygen quantum yields have been shown to be directly related to the aggregation state of the PS, that is, the quantum yield is low when the sensitizer is in an aggregated form. ${ }^{34,35}$ Also, the fluorescence of the PS will be reduced accordingly. Substitution of the macrocycle with bulky groups can reduce aggregation tendency by shielding of the Pc core. ${ }^{16,36}$ Moreover, axial substitution may be even more effective in reducing the formation of these stacks. ${ }^{13,18}$ Indeed, Figure 3 shows that $\mathrm{ZnPc}(\mathrm{sol})_{8}$ has a stronger tendency to aggregate as compared to $\mathrm{Si}(\mathrm{sol})_{2} \mathrm{Pc}$, demonstrating the higher efficiency of axial substitution in reducing the aggregation behavior. The strong aggregation tendency of $\mathrm{ZnPc}(\mathrm{sol})_{8}$ can explain why it could not be visualized intracellularly by LSCFM, despite its high uptake (Table 1), and why it did not show any photocytotoxicity upon illumination. Unlike $\mathrm{ZnPc}(\mathrm{sol})_{8}$, both $\mathrm{Si}(\mathrm{sol})_{2} \mathrm{Pc}$ and $\mathrm{Si}(\mathrm{PEG} 750)_{2} \mathrm{Pc}$ could be visualized by LSCFM and were photoactive, indicating that these PSs are not in an aggregated state inside the cell and that the axial substituents are effective in preventing stacking of the Pc rings.

When evaluating the $\mathrm{IC}_{50}$ values of the tested PSs, $\mathrm{Si}(\mathrm{sol})_{2} \mathrm{Pc}$ appears about 25 times more effective in inducing cell death upon illumination than $\mathrm{Si}(\mathrm{PEG} 750){ }_{2} \mathrm{Pc}$ in both B16F10 and $14 \mathrm{C}$ cells. The photocytotoxicity of $\mathrm{Si}(\mathrm{PEG} 750)_{2} \mathrm{Pc}$ is comparable to values reported previously for axially substituted SiPcs. ${ }^{13,14,37}$ For example, Huang et al. ${ }^{29}$ tested the same compound in HepG2 cells and found an $\mathrm{IC}_{50}$ concentration of $0.75 \mu \mathrm{M}$, which is about the same $\mathrm{IC}_{50}$ value we found for this compound in $\mathrm{B} 16 \mathrm{~F} 10$ and $14 \mathrm{C}$ cells. Interestingly, when $\mathrm{Si}(\mathrm{sol})_{2} \mathrm{Pc}$ and $\mathrm{Pc} 4$ are compared, they showed similar photodynamic activity $\left(\mathrm{IC}_{50}\right.$ values were comparable). Because the site of PS activity is supposed to be located intracellularly, as mentioned in the Introduction section, intracellular concentrations are more relevant as a measure for phototoxicity than the concentrations of PS added to the medium in the cell cultures (i.e., the $\mathrm{IC}_{50}$ values). However, the intracellular concentrations at the amounts of PS used in the phototoxicity studies are so low that it is impossible to measure intracellular concentrations. Therefore, just to get an indication about the cellular uptake, we measured fluorescence of cell lysates at much higher concentrations of added PS (i.e., $10 \mu \mathrm{M}$ ). The uptake of $\mathrm{Si}(\mathrm{sol})_{2} \mathrm{Pc}$ and Si(PEG750) ${ }_{2} \mathrm{Pc}$ by B16F10 and $14 \mathrm{C}$ cells was similar to the values reported by Cauchon et al. ${ }^{38}$ for sulfonated ZnPcs with alkyl substituents of various chain lengths. The cellular uptake of the latter compounds by EMT-6 cells was between 0.05 and 0.97 $\mathrm{ng} / \mathrm{mg}$ protein after incubation with $10 \mu \mathrm{M}$ PS for 1 or $24 \mathrm{~h}$. Although $\mathrm{Si}(\mathrm{sol})_{2} \mathrm{Pc}$ and $\mathrm{Si}(\mathrm{PEG} 750)_{2} \mathrm{Pc}$ were taken up to the same extent, $\mathrm{Si}(\mathrm{sol})_{2} \mathrm{Pc}$ was the most phototoxic one. More importantly, while $\mathrm{Pc} 4$ and $\mathrm{Si}(\mathrm{sol}){ }_{2} \mathrm{Pc}$ showed similar phototoxicity at equal amounts of PS added to the medium, the amount of PS taken up by B16F10 cells was about 25 times lower for $\mathrm{Si}(\mathrm{sol})_{2} \mathrm{Pc}$.

The above results indicate that the intracellular concentration of PS needed to affect cell death upon illumination was much less for $\mathrm{Si}(\mathrm{sol})_{2} \mathrm{Pc}$ than for $\mathrm{Pc} 4$, and that $\mathrm{Si}(\mathrm{sol})_{2} \mathrm{Pc}$ is more efficient than $\mathrm{Si}(\mathrm{PEG} 750)_{2} \mathrm{Pc}$ at equal intracellular concentration. It has been shown that the intracellular distribution of a PS is very important for the overall photodynamic effect. ${ }^{4}$ Singlet oxygen has a very short life span of about $0.03-0.18 \mu \mathrm{s}^{39}$ During that short time, its diffusion inside the cell was between 10 and $70 \mathrm{~nm} .^{40,41}$ These diffusion distances are very small compared to the dimensions of eukaryotic cells, which are in the order of $10-100 \mu \mathrm{m} .{ }^{23}$ This stresses the importance of the specific location of the PS inside the cell in order to be able to induce cell death. Localization of PSs in membranes of organelles like lysosomes or mitochondria have been reported to be most effective. ${ }^{9,42} \mathrm{Pc} 4$ mainly localizes in mitochondrial membranes, ${ }^{43}$ which is one of the main factors contributing to its high photodynamic efficacy. $\mathrm{Si}(\mathrm{sol})_{2} \mathrm{Pc}$ was found to be localized in lipid droplets. These compartments have been reported to be involved in PS accumulation only on very few occasions. ${ }^{44,45}$ However, those PSs are chlorin derivatives, and Pc-based compounds have not been explicitly mentioned before in this context. Interestingly, Lee et al. ${ }^{14}$ also observed a spotted pattern in HepG2 cells, much resembling our microscopic images, for a similar SiPc containing axial isopropylideneprotected galactose substituents. By incubation with MitoTracker green, they showed only minor colocalization with mitochondria. It is therefore very well possible that localization of the PS in lipid droplets was largely responsible for the pattern that they observed. In mammalian cells, lipid droplets are cell organelles that consist of neutral lipids surrounded by a monolayer of phospholipids and associated proteins. ${ }^{46,47}$ Among the membrane proteins found in lipid droplets are caveolin-1 and caveolin$2 .{ }^{48}$ These proteins are normally found as structural components of caveolae, ${ }^{49}$ a class of clathrin-independent vesicles involved in receptor-mediated endocytosis, ${ }^{50}$ which may suggest that $\mathrm{Si}$ $(\mathrm{sol})_{2} \mathrm{Pc}$ is actively taken up by the cells. However, as no difference in cellular uptake was observed between $4{ }^{\circ} \mathrm{C}$ and $37{ }^{\circ} \mathrm{C}$, it is unlikely that the $\mathrm{Si}(\mathrm{sol})_{2} \mathrm{Pc}$ was taken up by active transport. Time-dependent uptake studies have shown that it took $6 \mathrm{~h}$ of incubation at $37^{\circ} \mathrm{C}$ to reach equilibrium, which was the standard incubation period in our experiments (results not shown). If possible alterations in membrane properties (increased membrane rigidity, for example) would have played a role in the diffusion-driven uptake rate at $4{ }^{\circ} \mathrm{C}$, one would expect that equilibrium is obtained more slowly at the lower temperature. This was likely not the case, because we observed similar uptake after $6 \mathrm{~h}$ at $4{ }^{\circ} \mathrm{C}$ and at $37{ }^{\circ} \mathrm{C}$. Probably, intracellular complexation of the PS with certain proteins or other lipid droplet constituents is responsible for the observed localization of the PS in lipid droplets.

The difference in photodynamic activity between $\mathrm{Si}(\mathrm{sol}){ }_{2} \mathrm{Pc}$ and $\mathrm{Si}(\mathrm{PEG} 750)_{2} \mathrm{Pc}$ is most likely due to their different intracellular distribution, that is, the latter PS is not specifically located in membrane containing cellular compartments, but is homogeneously distributed inside the cell, owing to its greater hydrophilicity. In view of the proposed preferred localization site of PSs, for example, in mitochondrial membranes, the similar photodynamic efficacy of $\mathrm{Si}(\mathrm{sol})_{2} \mathrm{Pc}$ and $\mathrm{Pc} 4$ is remarkable, especially because the former PS is present at lower intracellular concentrations. This would suggest that lipid droplets are very effective targets for PDT. On the other hand, it is also possible that the localization of $\mathrm{Si}(\mathrm{sol})_{2} \mathrm{Pc}$ in lipid droplets is not the prime reason for its high phototoxicity, because redistribution of this compound over the cytosol was observed upon illumination (Figure 5c). Similar behavior has been found by Liu et al. ${ }^{51}$ who observed that PSs, that is, $\mathrm{ZnPc}$ derivatives containing carboxylate groups accumulated in lysosomes and redistributed upon brief light exposure. Redistribution of $\mathrm{Si}(\mathrm{sol})_{2} \mathrm{Pc}$ may be due to the destruction of the lipid droplets by ROS. On the other hand, it has been shown previously that acetals and ketals can be photochemically deprotected by a catalytic amount of PS. ${ }^{52,53}$ Therefore, the redistribution of $\mathrm{Si}(\mathrm{sol})_{2} \mathrm{Pc}$ could also be the result of the removal of the ketal functionality under the illumination conditions, leading to the formation of a more hydrophilic Pc 
containing two axial 1,2-diols, which could dissolve in the cytosol or other organelles. The possibility of light-induced conversion of the solketal groups in close proximity of the Pc ring is highly interesting, and this will be the subject of future investigations. Thus, it remains elusive whether redistribution, for example, to mitochondria, is essential for the high efficacy of the $\mathrm{Si}(\mathrm{sol})_{2} \mathrm{Pc}$ or if it is the result of disruption of the lipid droplet integrity, which itself could be responsible for inducing the observed photodynamic effect. Investigating the site of ROS formation $^{54-56}$ or determination of the activity of marker enzymes for specific organelles ${ }^{57,58}$ after illumination of cells incubated with $\mathrm{Si}(\mathrm{sol})_{2} \mathrm{Pc}$ could be a valuable tool to elucidate this phenomenon.

\section{Conclusions}

This study shows that the axially substituted $\mathrm{Si}(\mathrm{sol})_{2} \mathrm{Pc}$ has a much higher photocytotoxicity and a much lower tendency to aggregate than the peripherally substituted $\mathrm{ZnPc}(\mathrm{sol})_{8}$. This can be attributed to the effect of the axial substituents, which prevent stacking of the aromatic Pc rings. Despite its relatively low uptake compared to a known PS (Pc4), Si(sol) $)_{2} \mathrm{Pc}$ had a high phototoxic effect, with $\mathrm{IC}_{50}$ values comparable to those of Pc4. $\mathrm{Si}(\mathrm{sol})_{2} \mathrm{Pc}$ accumulated intracellularly in lipid droplets and redistributed upon illumination, which can be the reason for the high photodynamic activity. Increasing the cellular uptake by formulation of this PS in, for example, targeted micelles or liposomes might result in an even higher intracellular concentration and a concomitant increased photodynamic effect.

\section{Experimental Section}

Materials and Equipment for Synthesis. Chemicals were obtained from commercial sources and used without purification, unless stated otherwise. 1,3-Diiminoisoindoline was synthesized according to Sasa et al., ${ }^{27}$ with minor modifications in the workup procedure, that is, the reaction solvent was removed in vacuo, and the product was resuspended in $\mathrm{Et}_{2} \mathrm{O}$ before filtration. The product was used to prepare $\mathrm{Si}(\mathrm{Cl})_{2} \mathrm{Pc}$ according to a literature procedure. ${ }^{28}$ $\mathrm{Pc}^{59}$ was kindly donated by Prof. Dr. Nancy Oleinick, Case Western Reserve University School of Medicine, Cleveland, Ohio. Reactions were monitored by thin layer chromatography (TLC) on Merck precoated silica gel $60 \mathrm{~F}_{254}(0.25 \mathrm{~mm})$ plates or Merck precoated aluminum oxide $150 \mathrm{~F}_{254}$ neutral plates. Flash column chromatography was performed on Acros organics silica gel, $0.035-0.070 \mathrm{~mm}$, pore diameter about $6 \mathrm{~nm}$, or dried $\left(150{ }^{\circ} \mathrm{C}\right)$ neutral alumina (activity 1, ICN Biomedicals B.V., The Netherlands). NMR spectra were recorded on a Varian Gemini $300\left({ }^{1} \mathrm{H}\right.$ NMR at $300 \mathrm{MHz},{ }^{13} \mathrm{C} \mathrm{NMR}$ at $75.4 \mathrm{MHz}$ ) or a Varian Inova-500 $\left({ }^{1} \mathrm{H}\right.$ NMR at $\left.500 \mathrm{MHz}\right) .{ }^{13} \mathrm{C}$ NMR spectra were recorded using the attached proton test (APT) sequence. Chemical shifts are reported in ppm, relative to the solvent peak, and are given downfield from TMS. HPLC analyses were carried out using a Waters 2965 AllianceXC with a Waters 2487 dual wavelength UV detector and a Waters 2414 RI dectector. The oven temperature was set to 30 ${ }^{\circ} \mathrm{C}$. A Waters XTerra MS C18, $5 \mu \mathrm{m}, 4.6 \times 250 \mathrm{~mm}$ column was used for intermediates; an eluent gradient from $\mathrm{H}_{2} \mathrm{O} / \mathrm{MeCN}$ 95:5 to $\mathrm{H}_{2} \mathrm{O} / \mathrm{MeCN}$ 5:95 in $60 \mathrm{~min}$ at $1 \mathrm{~mL} / \mathrm{min}$ was run. Pcs were run on a Waters, sunfire $\mathrm{C} 18,5 \mu \mathrm{m}, 4.6 \times 150 \mathrm{~mm}$ column; eluent $\mathrm{H}_{2} \mathrm{O} / \mathrm{THF} 95: 5$ to $\mathrm{H}_{2} \mathrm{O} / \mathrm{THF}$ 5:95 in $60 \mathrm{~min}, 1 \mathrm{~mL} / \mathrm{min}$. GPC analysis of $\mathrm{Si}(\mathrm{PEG} 750)_{2} \mathrm{Pc}$ was done on a GPC system containing a Waters 600E gradient pump with a Waters 717 autosampler, connected to a Waters $486 \mathrm{UV}$ detector, set at $600 \mathrm{~nm}$, and a Waters 410 RI detector. The used column was an Oligopore, $300 \times 7.5$ $\mathrm{mm}$, Polymer Laboratories, with a guard column, oligopore guard, $50 \times 7.5 \mathrm{~mm}$, Polymer Laboratories. PEG standards were used for calibration. Samples were run in $\mathrm{CHCl}_{3}$ at $1 \mathrm{~mL} / \mathrm{min}$. Absorpion spectra were recorded on a Perkin-Elmer Lambda 2 UV-vis spectrometer. A Fluorolog, FL3-21, fluorescence spectrophotometer was used for fluorescence measurements. Electrospray ionization
(ESI) mass spectrometry was carried out on a Shimadzu LCMS QP-800 single quadrupole benchtop spectrometer, coupled to a QP800 data system. Melting points were determined using a TA Intruments DSC Q1000 machine. Scans were taken from 20 to 200 ${ }^{\circ} \mathrm{C}$ at a heating rate of $10{ }^{\circ} \mathrm{C} / \mathrm{min}$. Elemental analysis of the end products was done by $\mathrm{H}$. Kolbe, Mikroanalytisches Laboratorium, Mülheim an der Ruhr, Germany.

3,4-Dibromocatechol (4). Compound 4 was synthesized according to van Nostrum et al. ${ }^{25}$ Catechol was recrystallized from toluene before use. TLC (MTBE/hexane 1:1): $R_{f}=0.23 ; \mathrm{mp} 117^{\circ} \mathrm{C}$ (lit. $\left.119^{\circ} \mathrm{C}^{25}\right) .{ }^{1} \mathrm{H} \mathrm{NMR}\left(\mathrm{CDCl}_{3}\right): \delta 7.12\left(\mathrm{~s}, 2 \mathrm{H}, \mathrm{CH}^{\mathrm{Ar}}\right), 5.23(\mathrm{~s}, 2 \mathrm{H}$ $\mathrm{OH}) .{ }^{13} \mathrm{C} \mathrm{NMR}\left(\mathrm{CDCl}_{3}\right): \delta 143.46\left(\mathrm{C}^{\mathrm{Ar}}-\mathrm{OH}\right), 119.88\left(\mathrm{CH}^{\mathrm{Ar}}\right)$, $114.83\left(\mathrm{C}^{\mathrm{Ar}}-\mathrm{Br}\right)$.

1,2-Bis(allyloxy)-4,5-dibromobenzene (5). 3,4-Dibromocatechol (4; $5.00 \mathrm{~g}, 18.66 \mathrm{mmol}), \mathrm{Na}_{2} \mathrm{CO}_{3}$ (4.35 g, $41.06 \mathrm{mmol}$ ), and allylbromide $(4.97 \mathrm{~g}, 41.06 \mathrm{mmol})$ were suspended in acetone $(25$ $\mathrm{mL}$ ). The reaction mixture was refluxed for $44 \mathrm{~h}$, until TLC showed no monosubstituted product. After cooling to $\mathrm{rt}, \mathrm{H}_{2} \mathrm{O}(100 \mathrm{~mL})$ was added, and the product was extracted with $\mathrm{Et}_{2} \mathrm{O}(3 \times 100 \mathrm{~mL})$. The combined organic layers were washed with brine $(100 \mathrm{~mL})$ and dried over $\mathrm{Na}_{2} \mathrm{SO}_{4}$. Removal of the solvent in vacuo afforded $5(6.24 \mathrm{~g}, 96 \%)$ as a light yellow crystalline solid, which was pure according to TLC and NMR. TLC (MTBE/hexane 1:1): $R_{f}=0.58$; $\mathrm{mp} 41{ }^{\circ} \mathrm{C} .{ }^{1} \mathrm{H}$ NMR $\left(\mathrm{CDCl}_{3}\right): \delta 7.07\left(\mathrm{~s}, 2 \mathrm{H}, \mathrm{CH}^{\mathrm{Ar}}\right), 6.02(\mathrm{M}, 2 \mathrm{H}$, $\left.-\mathrm{CH}=\mathrm{CH}_{2}\right), 5.35\left(\mathrm{~m}, 4 \mathrm{H},=\mathrm{CH}_{2}\right), 4.54\left(\mathrm{~m}, 4 \mathrm{H}, \mathrm{O}-\mathrm{CH}_{2}\right) .{ }^{13} \mathrm{C}$ NMR (APT, $\left.\mathrm{CDCl}_{3}\right): \delta 148.28\left(\mathrm{qC}, \mathrm{C}^{\mathrm{Ar}}-\mathrm{O}\right), 132.39\left(\mathrm{CH}=\mathrm{CH}_{2}\right)$, $118.34\left(\mathrm{qC}, \mathrm{C}^{\mathrm{Ar}}-\mathrm{Br}\right), 118.32\left(\mathrm{CH}^{\mathrm{Ar}}\right), 115.00\left(\mathrm{CH}_{2}=\right), 70.15(\mathrm{O}-$ $\mathrm{CH}_{2}$ ). HPLC: $\mathrm{Rt}=38.6 \mathrm{~min}, 100 \%$.

3,3'-(4,5-Dibromo-1,2-phenylene)bis(oxy)dipropane-1,2-diol (6). Citric acid (11.04 g, $57.47 \mathrm{mmol}), 2$ (10.00 g, $28.73 \mathrm{mmol})$, and $\mathrm{OsO}_{4}\left(0.709 \mathrm{~mL}\right.$ of a $4 \mathrm{w}-\%$ solution in $\mathrm{H}_{2} \mathrm{O}, 0.4$ mol-\%) were added to $\mathrm{H}_{2} \mathrm{O} / \mathrm{t}-\mathrm{BuOH}(1: 1,60 \mathrm{~mL})$, yielding a green suspension. 4-Methylmorpholine-4- $N$-oxide (NMO, $14.81 \mathrm{~g}$ of a $50 \mathrm{w}-\%$ solution in $\mathrm{H}_{2} \mathrm{O}, 61.2 \mathrm{mmol}$ ) was added, and the reaction was stirred at $\mathrm{rt}$ for $2 \mathrm{~h}$. After removal of $t-\mathrm{BuOH}$ in vacuo, a $\mathrm{HCl}$ solution $(1 \mathrm{M}, 100 \mathrm{~mL})$ was added, followed by extraction with EtOAc (3 $\times 100 \mathrm{~mL}$ ). The combined organic layers were dried over $\mathrm{Na}_{2}-$ $\mathrm{SO}_{4}$. The solvent was removed in vacuo, yielding $\mathbf{6}$ as a white solid (11.30 g, 95\%). TLC $\left(\mathrm{CH}_{2} \mathrm{Cl}_{2} / \mathrm{MeOH} 5: 1\right): R_{f}=0.23 ; \mathrm{mp} 94{ }^{\circ} \mathrm{C}$. ${ }^{1} \mathrm{H} \mathrm{NMR}+\mathrm{COSY}\left(\mathrm{CD}_{3} \mathrm{OD}\right): \delta 7.26\left(\mathrm{~s}, 2 \mathrm{H}, \mathrm{CH}^{\mathrm{Ar}}\right), 4.06(\mathrm{~m}, 2 \mathrm{H}$, $\left.-\mathrm{CH}_{2}-\mathrm{CH}\right), 3.96\left(\mathrm{~m}, 4 \mathrm{H},-\mathrm{CH}-\mathrm{OH}, \mathrm{CH}_{2}{ }^{\prime}-\mathrm{CH}\right), 3.67(\mathrm{~m}, 4 \mathrm{H}$, $\left.\mathrm{CH}_{2}-\mathrm{OH}\right) .{ }^{13} \mathrm{C}$ NMR (APT, $\left.\mathrm{CD}_{3} \mathrm{OD}\right): \delta 150.42\left(\mathrm{qC}, \mathrm{C}^{\mathrm{Ar}}-\mathrm{O}\right)$, $119.77\left(\mathrm{CH}^{\mathrm{Ar}}\right), 116.10\left(\mathrm{qC}, \mathrm{C}^{\mathrm{Ar}}-\mathrm{Br}\right), 72.16\left(\mathrm{O}-\mathrm{CH}_{2}-\right), 71.59$ $(-\mathrm{CH}-\mathrm{OH}), 63.96\left(\mathrm{CH}_{2}-\mathrm{OH}\right)$. HPLC: $R_{\mathrm{t}}=17.3 \mathrm{~min}, 100 \%$.

4,4'-(4,5-Dibromo-1,2-phenylene)bis(oxy)bis(methylene)bis(2,2-dimethyl-1,3-dioxolane) (7). Compound 6 (500 mg, 1.20 $\mathrm{mmol})$ was suspended in DMP $(10 \mathrm{~mL})$. Upon addition of $p$-toluene sulfonic acid $(50 \mathrm{mg})$, the starting materials dissolved almost completely. The solution was stirred at $\mathrm{rt}$ for $30 \mathrm{~min}$. $\mathrm{NaHCO}_{3}$ (aq; $5 \mathrm{w}-\%, 20 \mathrm{~mL}$ ) was added, and the product was extracted with $\mathrm{CH}_{2} \mathrm{Cl}_{2}(2 \times 50 \mathrm{~mL})$. The combined organic layers were washed with $\mathrm{H}_{2} \mathrm{O}(3 \times 100 \mathrm{~mL})$ and dried over $\mathrm{Na}_{2} \mathrm{SO}_{4}$. Removal of the solvent in vacuo yielded an oil, which solidified upon storage to give 7 as a white product $(0.56 \mathrm{~g}, 94 \%)$. TLC (MTBE/ Hex 1:1): $R_{f}=0.45 ; \mathrm{mp} 81{ }^{\circ} \mathrm{C} .{ }^{1} \mathrm{H} \mathrm{NMR}\left(\mathrm{CDCl}_{3}\right): \delta 7.10\left(\mathrm{~s}, 2 \mathrm{H}, \mathrm{CH}^{\mathrm{Ar}}\right)$, $4.43,4.13,4.05,3.91\left(4 \mathrm{~m}, 2 \mathrm{H}, 2 \mathrm{H}, 2 \mathrm{H}, 4 \mathrm{H}, \mathrm{Ar}-\mathrm{OCH}_{2}, \mathrm{CH}-\mathrm{O}\right.$, $\left.\mathrm{CH}-\mathrm{CH}_{2}-\mathrm{O}\right), 1.43\left(\mathrm{~s}, 6 \mathrm{H}, \mathrm{CH}_{3}\right), 1.37\left(\mathrm{~s}, 6 \mathrm{H}, \mathrm{CH}_{3}{ }^{\prime}\right) .{ }^{13} \mathrm{C} \mathrm{NMR}$ $\left(\mathrm{APT}, \mathrm{CDCl}_{3}\right): \delta 148.51\left(\mathrm{qC}, \mathrm{C}^{\mathrm{Ar}}-\mathrm{O}\right), 118.97\left(\mathrm{CH}^{\mathrm{Ar}}\right), 115.64(\mathrm{qC}$, $\left.\mathrm{C}^{\mathrm{Ar}}-\mathrm{Br}\right), 109.73(\mathrm{qC}, \mathrm{O}-\mathrm{C}-\mathrm{O}), 73.76(\mathrm{CH}-\mathrm{O}), 70.10(\mathrm{Ar}-\mathrm{O}-$ $\left.\mathrm{CH}_{2}\right), 66.55\left(\mathrm{O}-\mathrm{CH}_{2}\right), 26.66\left(\mathrm{CH}_{3}\right), 25.35\left(\mathrm{CH}_{3}{ }^{\prime}\right)$. HPLC: $R_{\mathrm{t}}=$ $36.8 \mathrm{~min}, 99.3 \%$.

4,5-Bis[(2,2-dimethyl-1,3-dioxolan-4-yl)methoxy]phthalonitrile (8). A 3-neck flask $(250 \mathrm{~mL})$ with a cooler and oil lock were dried at $150{ }^{\circ} \mathrm{C}$ and allowed to cool to rt under a $\mathrm{N}_{2}$ flow. The flask was charged with freshly distilled DMF $(100 \mathrm{~mL})$ and $7(5.00$ $\mathrm{g}, 10.08 \mathrm{mmol}$ ). The suspension was stirred under a $\mathrm{N}_{2}$ flow until all the starting material was dissolved. $\mathrm{CuCN}(2.70 \mathrm{~g}, 30.23 \mathrm{mmol})$ and pyridine $(2.45 \mathrm{~mL}, 30.23 \mathrm{mmol})$ were added followed by refluxing overnight. The suspension was poured into a beaker containing $28-30 \%$ ammonia $(50 \mathrm{~mL})$. Another $50 \mathrm{~mL}$ of ammonia was used to rinse the reaction flask. Air was bubbled through for 
$2.5 \mathrm{~h}$, upon which the color changed from green to blue. The product was extracted with $\mathrm{CH}_{2} \mathrm{Cl}_{2}(4 \times 150 \mathrm{~mL})$. The combined organic layers were washed with $\mathrm{H}_{2} \mathrm{O}(4 \times 150 \mathrm{~mL})$ and dried over $\mathrm{Na}_{2}-$ $\mathrm{SO}_{4}$, and the solvent was removed in vacuo, yielding the crude product as a dark green solid (99\%). The product was purified by flash chromatography (MTBE/hexane 2:1) to afford $8(2.31 \mathrm{~g}, 59 \%)$. TLC (MTBE/hexane 2:1): $R_{f}=0.38 ; \mathrm{mp} 124{ }^{\circ} \mathrm{C} .{ }^{1} \mathrm{H}$ NMR $\left(\mathrm{CDCl}_{3}\right): \delta 7.19\left(\mathrm{~m}, 2 \mathrm{H}, \mathrm{CH}^{\mathrm{Ar}}\right), 4.47,4.17-4.12,3.92(3 \mathrm{~m}, 2 \mathrm{H}$, $\left.6 \mathrm{H}, 2 \mathrm{H}, \mathrm{Ar}-\mathrm{O}-\mathrm{CH}_{2}, \mathrm{CH}-\mathrm{O}, \mathrm{CH}-\mathrm{CH}_{2}-\mathrm{O}\right), 1.42\left(\mathrm{~s}, 6 \mathrm{H}, \mathrm{CH}_{3}\right)$, $1.37\left(\mathrm{~s}, 6 \mathrm{H}, \mathrm{CH}_{3}{ }^{\prime}\right) .{ }^{13} \mathrm{C}$ NMR (APT, $\left.\mathrm{CDCl}_{3}\right): \delta 151.86\left(\mathrm{qC}, \mathrm{C}^{\mathrm{Ar}}-\right.$ $\mathrm{O}), 116.65\left(\mathrm{CH}^{\mathrm{Ar}}\right), 115.52(\mathrm{qC}, \mathrm{CN}), 109.94(\mathrm{qC}, \mathrm{O}-\mathrm{C}-\mathrm{O}), 108.95$ $\left(\mathrm{qC}, \mathrm{C}^{\mathrm{Ar}}-\mathrm{CN}\right), 73.41(\mathrm{CH}-\mathrm{O}), 69.60\left(\mathrm{Ar}-\mathrm{O}-\mathrm{CH}_{2}\right), 66.06(\mathrm{O}-$ $\left.\mathrm{CH}_{2}\right), 26.47\left(\mathrm{CH}_{3}\right), 25.22\left(\mathrm{CH}_{3}{ }^{\prime}\right)$. ESI-MS: $m / z 406.65(100 \%$, [M $\left.\left.+\mathrm{NH}_{4}\right]^{+}\right) ; 389.15\left(7 \%,[\mathrm{M}+\mathrm{H}]^{+}\right)$. HPLC: $R_{\mathrm{t}}=29.3 \mathrm{~min}, 98.7 \%$.

$\mathbf{Z n P c}(\mathbf{s o l})_{8}$ (1). A Schlenk flask (dried at $150{ }^{\circ} \mathrm{C}$ and cooled to rt under an Ar flow), charged with $8(232 \mathrm{mg}, 0.60 \mathrm{mmol})$ and $\mathrm{Zn}(\mathrm{OAc})_{2}(24 \mathrm{mg}, 0.13 \mathrm{mmol})$ was evacuated and refilled with $\mathrm{N}_{2}$ $(3 \times) . N, N$-Dimethylaminoethanol $(3 \mathrm{~mL})$ was added through a septum, and the suspension was refluxed for $24 \mathrm{~h}$. A clear solution was obtained upon heating, which turned green within $1 \mathrm{~h}$. The solvent was removed in vacuo, and the crude product was purified by gradient flash chromatography (EtOAc/hexane 2:1 to EtOAc), yielding $\mathrm{ZnPc}(\mathrm{sol})_{8}(164 \mathrm{mg}, 68 \%)$ as a green powder. TLC $\left(\mathrm{CH}_{2-}\right.$ $\left.\mathrm{Cl}_{2} / \mathrm{MeOH} 10: 1\right): R_{f}=0.26 .{ }^{1} \mathrm{H} \mathrm{NMR}+\mathrm{COSY}\left(\mathrm{DMSO}-d_{6}\right): \delta$ 8.80 (br s, 8H, H-Pc), 4.73 (m, 8H, $\mathrm{Ar}-\mathrm{O}-\mathrm{CH}_{2}$ ), 4.64 (m, 16H, $\left.\mathrm{Ar}-\mathrm{O}-\mathrm{CH}_{2}{ }^{\prime}, \mathrm{CH}-\mathrm{CH}_{2}-\mathrm{O}\right), 4.33(\mathrm{~m}, 8 \mathrm{H}, \mathrm{CH}-\mathrm{O}), 4.13(\mathrm{~m}, 8 \mathrm{H}$, $\left.\mathrm{CH}-\mathrm{CH}_{2}{ }^{\prime}-\mathrm{O}\right), 1.58\left(\mathrm{~s}, 24 \mathrm{H}, \mathrm{CH}_{3}\right), 1.45\left(\mathrm{~s}, 24 \mathrm{H}, \mathrm{CH}_{3}{ }^{\prime}\right) .{ }^{13} \mathrm{C} \mathrm{NMR}$ $\left(\right.$ APT, DMSO- $\left.d_{6}\right): \delta 151.64,150.40\left(2 \times \mathrm{qC}, \mathrm{C}^{\mathrm{Ar}}-\mathrm{O}, \mathrm{C}-\mathrm{N}\right)$, $131.72(\mathrm{qC}, C-\mathrm{C}-\mathrm{N}), 109.10(\mathrm{qC}, \mathrm{O}-\mathrm{C}-\mathrm{O}), 106.06\left(\mathrm{CH}^{\mathrm{Ar}}\right), 74.22$ $(\mathrm{CH}-\mathrm{O}), 70.10\left(\mathrm{Ar}-\mathrm{O}-\mathrm{CH}_{2}\right), 66.02\left(\mathrm{O}-\mathrm{CH}_{2}\right), 26.70\left(\mathrm{CH}_{3}\right), 25.70$ $\left(\mathrm{CH}_{3}{ }^{\prime}\right) . \mathrm{UV}-\mathrm{vis}(\mathrm{DMF}): \lambda_{\max }(\log \epsilon) 673(5.65), 644$ (4.81), 607 (4.84), 359 (5.23) nm. Fluorescence (DMF): $\lambda_{\mathrm{ex}, \max } 673, \lambda_{\mathrm{em}, \max }$ $678 \mathrm{~nm}$. Anal. $\left(\mathrm{C}_{80} \mathrm{H}_{96} \mathrm{~N}_{8} \mathrm{O}_{24} \mathrm{Zn}\right) \mathrm{C}, \mathrm{H}, \mathrm{N}, \mathrm{Zn}$ (see Supporting Information).

Si(sol) $)_{2} \mathbf{P c}$ (2). A flask and cooler were dried at $150{ }^{\circ} \mathrm{C}$ and cooled under an $\mathrm{Ar}$ flow. $\mathrm{Si}(\mathrm{Cl})_{2} \mathrm{Pc}(2.00 \mathrm{~g}, 3.27 \mathrm{mmol})$ and $\mathrm{NaH}(432$ $\mathrm{mg}, 18.0 \mathrm{mmol}$ ) were added, and the set up was evacuated and refilled with $\operatorname{Ar}(3 \times)$. Toluene $(160 \mathrm{~mL}$, dried on mol. sieves $(4$ $\AA$ )) was added through a septum, followed by the addition of solketal ( $895 \mu \mathrm{L}, 7.20 \mathrm{mmol})$. After stirring for $15 \mathrm{~min}$, the reaction mixture was refluxed for 3 days under a $\mathrm{N}_{2}$ atmosphere. The resulting green reaction mixture was allowed to cool to rt, and the solvent was removed in vacuo. The crude product was purified by flash chromatography $\left(\mathrm{CH}_{2} \mathrm{Cl}_{2} / \mathrm{EtOAc} 10: 1\right)$ with predried silica $\left(150{ }^{\circ} \mathrm{C}\right)$ to afford $\mathrm{Si}(\mathrm{sol})_{2} \mathrm{Pc}$ as a blue solid $(1.10 \mathrm{~g}, 42 \%)$. TLC $\left(\mathrm{CH}_{2} \mathrm{Cl}_{2} / \mathrm{EtOAc} 10: 1\right): R_{f}=0.54 .{ }^{1} \mathrm{H} \mathrm{NMR}+\mathrm{COSY}\left(\mathrm{CDCl}_{3}\right): \delta$ $9.61\left(\mathrm{~m}, 8 \mathrm{H}, \mathrm{H}_{\alpha}-\mathrm{Pc}\right), 8.32\left(\mathrm{~m}, 8 \mathrm{H}, \mathrm{H}_{\beta}-\mathrm{Pc}\right), 1.70(\mathrm{~m}, 2 \mathrm{H}, \mathrm{CH}-$ $\left.\mathrm{CH}_{2}-\mathrm{O}\right), 0.93(\mathrm{~m}, 2 \mathrm{H}, \mathrm{CH}-\mathrm{O}), 0.44\left(\mathrm{~m}, 2 \mathrm{H}, \mathrm{CH}-\mathrm{CH}_{2}^{\prime}-\mathrm{O}\right), 0.29$ $\left(\mathrm{s}, 6 \mathrm{H}, \mathrm{CH}_{3}\right),-0.03$ (s, 6H, $\left.\mathrm{CH}_{3}{ }^{\prime}\right),-2.00\left(\mathrm{~m}, 4 \mathrm{H}, \mathrm{Si}-\mathrm{O}-\mathrm{CH}_{2}\right)$. ${ }^{13} \mathrm{C} \mathrm{NMR}\left(\mathrm{APT}, \mathrm{CDCl}_{3}\right): \delta 149.25(\mathrm{qC}, \mathrm{N}-\mathrm{C}=\mathrm{N}), 135.90(\mathrm{qC}$, $\left.\mathrm{A}^{\mathrm{Ar}}\right), 130.91,123.71\left(\mathrm{C}^{\mathrm{Ar}}-\mathrm{H}_{\alpha}, \mathrm{C}^{\mathrm{Ar}}-\mathrm{H}_{\beta}\right), 107.20(\mathrm{qC}, \mathrm{O}-\mathrm{C}-\mathrm{O})$, $73.07(\mathrm{CH}-\mathrm{O}), 64.89\left(\mathrm{O}-\mathrm{CH}_{2}\right), 56.32\left(\mathrm{Ar}-\mathrm{O}-\mathrm{CH}_{2}\right), 24.99\left(\mathrm{CH}_{3}\right)$, $24.57\left(\mathrm{CH}_{3}{ }^{\prime}\right)$. UV-vis (DMF): $\lambda_{\max }(\log \epsilon) 674$ (5.45), 645 (4.56), 606 (4.63), 355 (4.93) nm. Fluorescence (DMF): $\lambda_{\text {ex,max }} 674 ; \lambda_{\text {em,max }}$ $678 \mathrm{~nm}$. Anal. $\left(\mathrm{C}_{44} \mathrm{H}_{38} \mathrm{~N}_{8} \mathrm{O}_{6} \mathrm{Si}\right) \mathrm{C}, \mathrm{H}, \mathrm{N}, \mathrm{Si}$ (see Supporting Information).

$\mathrm{Si}(\text { PEG750) })_{2} \mathbf{P c}$ (3). The synthesis of $\mathrm{Si}(\mathrm{PEG} 750)_{2} \mathrm{Pc}$ was essentially carried out according to Huang et al. ${ }^{29}$ Monomethoxy PEG $\left(M_{n}=750 \mathrm{~g} \cdot \mathrm{mol}^{-1}\right.$, Aldrich $)$ was dried as a solution in toluene $(0.1 \mathrm{mmol} / \mathrm{mL})$ over mol. sieves $(4 \AA)$. A 3-neck flask $(500 \mathrm{~mL})$ and cooler were dried at $150{ }^{\circ} \mathrm{C}$ and cooled under a $\mathrm{N}_{2}$ flow. $\mathrm{Si}(\mathrm{Cl})_{2^{-}}$ $\mathrm{Pc}(2.00 \mathrm{~g}, 3.27 \mathrm{mmol})$ and $\mathrm{NaH}(432 \mathrm{mg}, 18.0 \mathrm{mmol})$ were added, and the setup was evacuated and refilled with $\operatorname{Ar}(3 \times)$. The dried solution of PEG in toluene $(72 \mathrm{~mL}, 7.20 \mathrm{mmol})$ was added followed by additional toluene ( $92 \mathrm{~mL}$, dried on mol. sieves $4 \AA$ ). After stirring for 3 days at reflux and cooling to $\mathrm{rt}$, the solvent was removed in vacuo, and the crude green product was purified twice by flash chromatography $\left(\mathrm{CH}_{2} \mathrm{Cl}_{2} / \mathrm{EtOAc} 60: 1\right)$ with $\mathrm{Al}_{2} \mathrm{O}_{3}$ to afford $\mathrm{Si}(\mathrm{PEG} 750)_{2} \mathrm{Pc}$ as a blue paste $(1.31 \mathrm{~g}, 20 \%)$. TLC (neutral $\mathrm{Al}_{2} \mathrm{O}$, $\left.\mathrm{CH}_{2} \mathrm{Cl}_{2} / \mathrm{EtOH} 60: 1\right): R_{f}=0.54 .{ }^{1} \mathrm{H} \mathrm{NMR}\left(\mathrm{CDCl}_{3}\right): \delta 9.61(\mathrm{~m}$, $\left.8 \mathrm{H}, \mathrm{H}_{\alpha}-\mathrm{Pc}\right), 8.32\left(\mathrm{~m}, 8 \mathrm{H}, \mathrm{H}_{\beta}-\mathrm{Pc}\right), 3.62-3.48$ (m, app. $136 \mathrm{H}, \mathrm{CH}_{2}$
PEG), 3.43 (m, 4H, $\left.\mathrm{Si}-\mathrm{O}-\left(\mathrm{CH}_{2} \mathrm{CH}_{2} \mathrm{O}\right)_{3}-\mathrm{CH}_{2}\right), 3.35$ (s, $\left.6 \mathrm{H}, \mathrm{CH}_{3}\right)$, $3.19\left(\mathrm{t}, 4 \mathrm{H}, \mathrm{Si}-\mathrm{O}-\left(\mathrm{CH}_{2} \mathrm{CH}_{2} \mathrm{O}\right)_{2}-\mathrm{CH}_{2} \mathrm{CH}_{2},{ }^{3} \mathrm{~J}=4.88 \mathrm{~Hz}\right), 2.94$ (t, $\left.4 \mathrm{H}, \mathrm{Si}-\mathrm{O}-\left(\mathrm{CH}_{2} \mathrm{CH}_{2} \mathrm{O}\right)_{2}-\mathrm{CH}_{2},{ }^{3} J=4.88 \mathrm{~Hz}\right), 2.42(\mathrm{t}, 4 \mathrm{H}, \mathrm{Si}-$ $\left.\mathrm{O}-\mathrm{CH}_{2} \mathrm{CH}_{2} \mathrm{O}-\mathrm{CH}_{2} \mathrm{CH}_{2},{ }^{3} \mathrm{~J}=4.88 \mathrm{~Hz}\right), 1.64\left(\mathrm{t}, 4 \mathrm{H}, \mathrm{Si}-\mathrm{O}-\mathrm{CH}_{2-}\right.$ $\left.\mathrm{CH}_{2} \mathrm{O}-\mathrm{CH}_{2},{ }^{3} \mathrm{~J}=4.88 \mathrm{~Hz}\right), 0.44\left(\mathrm{t}, 4 \mathrm{H}, \mathrm{Si}-\mathrm{O}-\mathrm{CH}_{2} \mathrm{CH}_{2},{ }^{3} \mathrm{~J}=\right.$ $5.86,5.37 \mathrm{~Hz}),-1.94\left(\mathrm{t}, 4 \mathrm{H}, \mathrm{Si}-\mathrm{O}-\mathrm{CH}_{2},{ }^{3} \mathrm{~J}=5.37,5.86 \mathrm{~Hz}\right)$. ${ }^{13} \mathrm{C} \mathrm{NMR}\left(\mathrm{CDCl}_{3}, \mathrm{APT}\right): \delta 149.18(\mathrm{qC}, \mathrm{N}-\mathrm{C}=\mathrm{N}) ; 135.97\left(\mathrm{C}^{\mathrm{Ar}}-\right.$ $\mathrm{H}_{\alpha}$ or $\left.\mathrm{C}^{\mathrm{Ar}}-\mathrm{H}_{\beta}\right), 130.81\left(\mathrm{qC}, \mathrm{A}^{\mathrm{Ar}}\right), 70.54,69.78,69.33,68.56\left(\mathrm{CH}_{2}\right.$ PEG), $59.01\left(\mathrm{CH}_{3} \mathrm{PEG}\right)$. UV-vis (DMF): $\lambda_{\max }(\log \epsilon) 674$ (5.31), 644 (4.46), 606 (4.52), 355 (4.81) nm. Fluorescence (DMF): $\lambda_{\text {ex,max }}$ $674, \lambda_{\text {em,max }} 678 \mathrm{~nm}$. Anal. $\left(\mathrm{C}_{102} \mathrm{H}_{158} \mathrm{~N}_{8} \mathrm{O}_{36} \mathrm{Si}\right) \mathrm{C}, \mathrm{H}, \mathrm{N}, \mathrm{Si}$ (see Supporting Information). GPC: $M_{\mathrm{p}}=2023 \mathrm{~g} \cdot \mathrm{mol}^{-1} ; M_{n}=1900$, $M_{\mathrm{w}}=1950 \mathrm{~g} \cdot \mathrm{mol}^{-1}$

Aggregation Behavior. Increasing amounts of $\mathrm{H}_{2} \mathrm{O}$ were added to PS solutions $(5 \mu \mathrm{M})$ of $\mathrm{Si}(\mathrm{sol})_{2} \mathrm{Pc}$ and $\mathrm{ZnPc}(\mathrm{sol})_{8}$ in $\mathrm{DMF}$, and absorbance spectra were recorded immediately after the addition of $\mathrm{H}_{2} \mathrm{O}$. The maximal absorbance $\left(A_{\max }\right)$, corrected for dilution, of the Q-band was plotted against the dielectric constant $(\epsilon)$ of the solvent mixture, which was calculated according to the formula $\epsilon$ $=\left(\epsilon_{\text {water }} \times \mathrm{H}_{2} \mathrm{O}(\mathrm{v}-\%)+\epsilon_{\mathrm{DMF}} \times \mathrm{DMF}(\mathrm{v}-\%)\right) / 100$, with $\epsilon_{\text {water }}=$ $78.54\left(25^{\circ} \mathrm{C}\right)$ and $\epsilon_{\mathrm{DMF}}=37.52\left(25^{\circ} \mathrm{C}\right)$.

Materials and Equipment for Cell Culture. The murine B16F10 cell line was kindly provided by Prof. Dr. Ernst Wagner (Pharmaceutical Biology-Biotechology, Department of Pharmacy, Ludwig-Maximilans-Universität, Munich, Germany) and was originally obtained from I. J. Fidler (Texas Medical Center, Houston, U.S.A.). B16F10 cells were cultured in DMEM (Dulbecco's modification of Eagle's Medium, with $3.7 \mathrm{~g} / \mathrm{L}$ sodium bicarbonate, $1 \mathrm{~g} / \mathrm{L}$ glucose, Gibco BRL, Breda, The Netherlands), completed with antibiotics/antimycotics (100 IU penicilillin $\mathrm{G}$ sodium/mL, 100 $\mu \mathrm{g}$ streptomycin sulfate $/ \mathrm{mL}$ and $0.25 \mu \mathrm{g}$ amphotericin $\mathrm{B} / \mathrm{mL}$, Gibco BRL, Breda, The Netherlands), L-glutamine (2 mM, Gibco BRL, Breda, The Netherlands), and 10\% Foetal Bovine Serum (FBS, Integro, Zaandam, The Netherlands).

The human head and neck squamous cell carcinoma cell line UM-SCC-14C (developed by Dr. T.E. Carey, Ann Arbor, MI, and further abbreviated as 14C) was kindly provided by Prof. Dr. G.A.M.S. van Dongen (Department of Otolaryngology/Head and Neck Surgery, VU University Medical Center, Amsterdam, The Netherlands). This cell line was cultured in DMEM with $3.7 \mathrm{~g} / \mathrm{L}$ sodium bicarbonate, $4.5 \mathrm{~g} / \mathrm{L}$ glucose, Gibco BRL, Breda, The Netherlands), completed with antibiotics/antimycotics (100 IU penicillin $\mathrm{G}$ sodium $/ \mathrm{mL}, 100 \mu \mathrm{g}$ streptomycin sulfate $/ \mathrm{mL}$, and 0.25 $\mu \mathrm{g}$ amphotericin B/mL, Gibco BRL, Breda, The Netherlands), and $5 \%$ foetal bovine serum (FBS, Integro, Zaandam, The Netherlands).

For illumination of cells, a homemade device consisting of 96 LED lamps ( $670 \pm 10 \mathrm{~nm}, 1 \mathrm{LED} /$ well) was used, connected to a water bath thermostated at $37^{\circ} \mathrm{C}$. The well plate was placed on top of the instrument. The space between the plate and the lamps was used for water circulation. This water layer did not only give a constant temperature, but also a more homogeneous illumination area. Illumination time and intensity could be adjusted by the controller. The emitted light intensity was measured at the height of the well plate by an Orion Laser power/energy monitor (Ophir Optronics LTD, Jerusalem, Israel).

Photocytotoxicity. Cells were seeded in 96-well tissue culture plates (Greiner) at $2 \times 10^{4}$ cells per well $(100 \mu \mathrm{L}$ cell suspension) and incubated overnight at $37^{\circ} \mathrm{C}$ under $5 \% \mathrm{CO}_{2}$ to reattach. Freshly prepared stock solutions of the PSs in DMF or THF $(0.2$ or $2 \mathrm{mg} /$ $\mathrm{mL}$ ) were diluted in medium. The concentration of organic solvent was never higher than $0.5 \%$ : a concentration at which no effect on the cell viability was observed. The medium was removed from the wells and $100 \mu \mathrm{L}$ of fresh medium containing different concentration of PS were added to the wells, and the plates were incubated at $37{ }^{\circ} \mathrm{C}$ in $5 \% \mathrm{CO}_{2}$ for $6 \mathrm{~h}$. For every plate, another identical plate was prepared, which was kept in the dark. After incubation, the medium was removed and the cells were washed twice with $100 \mu \mathrm{L}$ PBS, and $100 \mu \mathrm{L}$ of fresh medium was added. The plates were illuminated for $10 \mathrm{~min}$ with $3.5 \mathrm{~mW} / \mathrm{cm}^{2}$ light intensity. Similar to previously reported procedures, ${ }^{38,51}$ the cells were incubated overnight at $37^{\circ} \mathrm{C}$ in $5 \% \mathrm{CO}_{2}$ atmosphere, and the 
cell survival, relative to cells without added PS, was then determined by a colorimetric assay, using the tetrazolium salt XTT (sodium 2,3-bis(2-methoxy-4-nitro-5-sulfophenyl)-2H-tetrazolium-5-carboxanilide $^{60}$ (Sigma-Aldrich), according to the manufacturers instructions. With this assay the mitochondrial activity is evaluated, which is a measure of cell viability because the cells were incubated for an extended period of time (16 h) after illumination.

Cellular Uptake. B16F10 cells and 14C cells were seeded in a 24-well plate at $15 \times 10^{4}$ cell per well (1000 $\mu \mathrm{L}$ cell suspension), and the plates were incubated overnight at $37{ }^{\circ} \mathrm{C}$ in a $5 \% \mathrm{CO}_{2}$ atmosphere. The medium was removed, and $500 \mu \mathrm{L}$ of fresh medium, containing $10 \mu \mathrm{M}$ of PS, was added, and the cells were incubated for $6 \mathrm{~h}$ at $37^{\circ} \mathrm{C}$ and $5 \% \mathrm{CO}_{2}$. Medium was removed, and the cells were washed twice with $500 \mu \mathrm{L}$ of PBS. To lyse the cells, $500 \mu \mathrm{L}$ of lysis buffer $(50 \mathrm{mM}$ tris $/ \mathrm{HCl}(\mathrm{pH} 8), 150 \mathrm{mM}$ $\mathrm{NaCl}$, and $1 \%$ Triton $\mathrm{X}-100$ ) was added, followed by incubation on ice for $20 \mathrm{~min}$. The concentration of PS in the cell lysate was determined by dilution of $100 \mu \mathrm{L}$ of the cell lysate with $900 \mu \mathrm{L}$ of $\mathrm{DMF}$ and measuring the fluorescence of the samples $\left(\lambda_{\mathrm{ex}}=355\right.$ $\mathrm{nm}, \lambda_{\mathrm{em}}=679 \mathrm{~nm}$ ). Calibration curves were prepared by dilution of PS stock solutions in DMF with cell lysate to a final lysate concentration of $10 \%(\mathrm{v} / \mathrm{v})$. An aliquot $(20 \mu \mathrm{L})$ of each lysate was used for determination of the cellular protein content, with the Micro BCA protein assay ${ }^{61}$ (Pierce, Rockford, U.S.A.), according to the instructions of the supplier. The uptake of PS was calculated as nmol Pc per mg of cellular protein. For evaluation of the cellular uptake at $4{ }^{\circ} \mathrm{C}$, medium, PS stock, and cells were cooled on ice before use. Operations were carried out on ice and incubations were done at $4{ }^{\circ} \mathrm{C}$. The amount of PS taken up was determined according to the procedure described above.

Intracellular Localization. To promote cell adhesion on the plates, $35 \mathrm{~mm}$ glass bottom microwell dishes (MatTek Corporation, Ashland, U.S.A.) were precoated with gelatin (Sigma) solution (1: 10 dilution in PBS) by incubation for $4 \mathrm{~h}$ at $37^{\circ} \mathrm{C}$. Cell suspensions of $14 \mathrm{C}$ or $\mathrm{B} 16 \mathrm{~F} 10$ cells $\left(2 \times 10^{4}\right.$ cells in $\left.1.5 \mathrm{~mL}\right)$ were added to the plates, and they were incubated overnight at $37{ }^{\circ} \mathrm{C}, 5 \% \mathrm{CO}_{2}$. The medium was removed, and PS solution $(1.5 \mathrm{~mL}, 1 \mu \mathrm{M})$ diluted in medium and supplemented with FBS was added. The cells were incubated for $6 \mathrm{~h}$, and the plates were examined with a confocal microscope in regular time intervals during the incubation. To visualize different organelles, cells preincubated for $6 \mathrm{~h}$ with or without PS were incubated with a number of tracker dyes, that is, Mytotracer green (Invitrogen, Breda, The Netherlands, $130 \mathrm{nM}$, from $0.1 \mathrm{mM}$ stock in DMSO), Lysotracker green (Invitrogen, 130 $\mathrm{nM}$, from $0.1 \mathrm{mM}$ stock in DMSO), Fluorescein isothiocyanatedextran (Sigma-Aldrich, FITC-dextran, 40 kDa, Sigma, $130 \mathrm{nM}$, from $0.1 \mathrm{mM}$ stock in DMSO), and Nile red (Invitrogen, $160 \mathrm{nM}$, from $1 \mathrm{mg} / \mathrm{mL}$ stock in DMSO). All dyes were incubated for 5 min at $37^{\circ} \mathrm{C}$, except for FITC-dextran, which was incubated for $10 \mathrm{~min}$. The cells were examined with a laser scanning confocal fluorescence microscope (Nikon Eclipse TE2000-U microscope), equipped with a $\mathrm{C} 1$ scanning unit, three exitation lasers, that is, argon-ion laser $(488 \mathrm{~nm}), \mathrm{He}-\mathrm{Ne}$ laser $(543 \mathrm{~nm})$, and $\mathrm{He}-\mathrm{Ne}$ laser $(633 \mathrm{~nm})$, two bandpass emission filters, that is, $515 / 30 \mathrm{~nm}$ and 585/30 nm, and one long-pass emission filter $(665 \mathrm{~nm})$.

Acknowledgment. This research was financially supported by NWO-CW/STW (Grant 790.36.110).

Supporting Information Available: A table with combustion analysis data of $\mathrm{ZnPc}(\mathrm{sol})_{8}, \mathrm{Si}(\mathrm{sol})_{2} \mathrm{Pc}$, and $\mathrm{Si}(\mathrm{PEG} 750)_{2} \mathrm{Pc}$ and a table with HPLC purity data of compounds $\mathbf{5}-\mathbf{8}$ are presented. This material is available free of charge via the Internet at http:// pubs.acs.org.

\section{References}

(1) Ackroyd, R.; Kelty, C.; Brown, N.; Reed, M. The history of photodetection and photodynamic therapy. Photochem. Photobiol. 2001, 74, 656-669.

(2) Bonnett, R. Progress with heterocyclic photosensitizers for the photodynamic therapy (PDT) of tumours. J. Heterocycl. Chem. 2002, $39,455-470$.
(3) Bonnett, R.; Martinez, G. Photobleaching of sensitisers used in photodynamic therapy. Tetrahedron 2001, 57, 9513-9547.

(4) Castano, A. P.; Demidova, T. N.; Hamblin, M. R. Mechanisms in photodynamic therapy: Part one-Photosensitizers, photochemistry and cellular localization. Photodiagn. Photodyn. Ther. 2004, 1, 279293.

(5) Lang, K.; Mosinger, J.; Wagnerova, D. M. Photophysical properties of porphyrinoid sensitizers noncovalently bound to host molecules; models for photodynamic therapy. Coord. Chem. Rev. 2004, 248, $321-350$.

(6) Detty, M. R.; Gibson, S. L.; Wagner, S. J. Current clinical and preclinical photosensitizers for use in photodynamic therapy. J. Med. Chem. 2004, 47, 3897-3915.

(7) Sternberg, E. D.; Dolphin, D.; Bruckner, C. Porphyrin-based photosensitizers for use in photodynamic therapy. Tetrahedron $\mathbf{1 9 9 8 ,}$ 54, 4151-4202.

(8) Allison, R. R.; Downie, G. H.; Cuenca, R.; Hu, X.-H.; Childs, C. J. H.; Sibata, C. H. Photosensitizers in clinical PDT. Photodiagn. Photodyn. Ther. 2004, 1, 27-42.

(9) Morgan, J.; Oseroff, A. R. Mitochondria-based photodynamic anticancer therapy. Adv. Drug Delivery Rev. 2001, 49, 71-86.

(10) Cassel, S.; Debaig, C.; Benvegnu, T.; Chaimbault, P.; Lafosse, M.; Plusquellec, D.; Rollin, P. Original synthesis of linear, branched and cyclic oligoglycerol standards. Eur. J. Org. Chem. 2001, 875-896.

(11) Chan, W. S.; Brasseur, N.; La Madeleine, C.; Ouellet, R.; van Lier, J. E. Efficacy and mechanism of aluminium phthalocyanine and its sulphonated derivatives mediated photodynamic therapy on murine tumours. Eur. J. Cancer 1997, 33, 1855-1859.

(12) Brasseur, N.; Ouellet, R.; La Madeleine, C.; van Lier, J. E. Watersoluble aluminium phthalocyanine-polymer conjugates for PDT: Photodynamic activities and pharmacokinetics in tumour-bearing mice. Br. J. Cancer 1999, 80, 1533-1541.

(13) Lo, P. C.; Huang, J. D.; Cheng, D. Y. Y.; Chan, E. Y. M.; Fong, W. P.; Ko, W. H.; Ng, D. K. P. New amphiphilic silicon(IV) phthalocyanines as efficient photosensitizers for photodynamic therapy: Synthesis, photophysical properties, and in vitro photodynamic activities. Chem.-Eur. J. 2004, 10, 4831-4838.

(14) Lee, P. P. S.; Lo, P. C.; Chan, E. Y. M.; Fong, W. P.; Ko, W. H.; $\mathrm{Ng}$, D. K. P. Synthesis and in vitro photodynamic activity of novel galactose-containing phthalocyanines. Tetrahedron Lett. 2005, 46, $1551-1554$.

(15) Jang, W. D.; Nakagishi, Y.; Nishiyama, N.; Kawauchi, S.; Morimoto, Y.; Kikuchi, M.; Kataoka, K. Polyion complex micelles for photodynamic therapy: Incorporation of dendritic photosensitizer excitable at long wavelength relevant to improved tissue-penetrating property. J. Controlled Release 2006, 113, 73-79.

(16) Kernag, C. A.; McGrath, D. V. Non-aggregating octasubstituted dendritic phthalocyanines. Chem. Commun. 2003, 9, 1048.

(17) De Filippis, M. P.; Dei, D.; Fantetti, L.; Roncucci, G. Synthesis of a new water-soluble octa-cationic phthalocyanine derivative for PDT. Tetrahedron Lett. 2000, 41, 9143-9147.

(18) Huang, J. D.; Choi, M. T. M.; Chan, W. K.; Chan, M. C.; Ng, D. K. P.; Fong, W. P.; Chan, E. Y. M. Photodynamic activities of a dicationic silicon(IV) phthalocyanine and its bovine serum albumin conjugates. Tetrahedron Lett. 2003, 44, 8029.

(19) Morris, R. L.; Azizuddin, K.; Lam, M.; Berlin, J.; Nieminen, A. L.; Kenney, M. E.; Samia, A. C. S.; Burda, C.; Oleinick, N. L. Fluorescence resonance energy transfer reveals a binding site of a photosensitizer for photodynamic therapy. Cancer Res. 2003, 63, 5194.

(20) Xue, L. Y.; Chiu, S. M.; Oleinick, N. L. Photochemical destruction of the Bcl-2 oncoprotein during photodynamic therapy with the phthalocyanine photosensitizer Pc 4. 2001, 20, 3420.

(21) Whitacre, C. M.; Feyes, D. K.; Satoh, T.; Grossmann, J.; Mulvihill, J. W.; Mukhtar, H.; Oleinick, N. L. Photodynamic therapy with the phthalocyanine photosensitizer Pc4 of SW480 human colon cancer xenografts in athymic mice. Clin. Cancer Res. 2000, 6, 2021.

(22) Morris, R. L.; Varnes, M. E.; Kenney, M. E.; Li, Y. S.; Azizuddin, K.; McEnery, M. W.; Oleinick, N. L. The peripheral benzodiazepine receptor in photodynamic therapy with the phthalocyanine photosensitizer Pc4. Photochem. Photobiol. 2002, 75, 652.

(23) Allen, C. M.; Sharman, W. M.; Van Lier, J. E. Current status of phthalocyanines in the photodynamic therapy of cancer. J. Porphyrins Phthalocyanines 2001, 5, 161-169.

(24) Pan, C. F.; Zhang, Z. H.; Sun, G. J.; Wang, Z. Y. Concise asymmetric synthesis of (5R)-6-hydroxy-3,8-dioxabicyclo[3.2.1] octane derivatives. Org. Lett. 2004, 6, 3059-3061.

(25) van Nostrum, C. F.; Picken, S. J.; Schouten, A. J.; Nolte, R. J. M. Synthesis and supramolecular chemistry of novel liquid-crystalline crown ether-substituted phthalocyanines toward molecular wires and molecular ionoelectronics. J. Am. Chem. Soc. 1995, 117, 9957-9965. 
(26) Dupau, P.; Epple, R.; Thomas, A. A.; Fokin, V. V.; Sharpless, K. B. Osmium-catalyzed dihydroxylation of olefins in acidic media: Old process, new tricks. Adv. Synth. Catal. 2002, 344, 421-433.

(27) Sasa, N.; Okada, K.; Nakamura, K.; Okada, S. Synthesis, structural and conformational analysis and chemical properties of phthalocyaninatometal complexes. J. Mol. Struct. 1998, 446, 163-178.

(28) Davison, J. B.; Wynne, K. J. Silicon phthalocyanine-siloxane polymers: Synthesis and ${ }^{1} \mathrm{H}$ nuclear magnetic resonance study. 1978, 11, 186-191.

(29) Huang, J. D.; Wang, S. Q.; Lo, P. C.; Fong, W. P.; Ko, W. H.; Ng, D. K. P. Halogenated silicon(IV) phthalocyanines with axial poly(ethylene glycol) chains. Synthesis, spectroscopic properties, complexation with bovine serum albumin and in vitro photodynamic activities. New J. Chem. 2004, 28, 348-354.

(30) Lo, P. C.; Wang, S. Q.; Zeug, A.; Meyer, M.; Roder, B.; Ng, D. K P. Preparation and photophysical properties of halogenated silicon(IV) phthalocyanines substituted axially with poly(ethylene glycol) chains. Tetrahedron Lett. 2003, 44, 1967-1970.

(31) Kimura, M.; Muto, T.; Takimoto, H.; Wada, K.; Ohta, K.; Hanabusa, K.; Shirai, H.; Kobayashi, N. Fibrous assemblies made of amphiphilic metallophthalocyanines. Langmuir 2000, 16, 2078-2082.

(32) Greenspan, P.; Mayer, E. P.; Fowler, S. D. Nile red: A selective fluorescent stain for intracellular lipid droplets. J. Cell. Biol. $\mathbf{1 9 8 5}$, $100,965-973$

(33) MacDonald, I. J.; Dougherty, T. J. Basic principles of photodynamic therapy. J. Porphyrins Phthalocyanines 2001, 5, 105.

(34) Wagner, J. R.; Ali, H.; Langlois, R.; Brasseur, N.; van Lier, J. E. Biological activities of phthalocyanines-VI. Photooxidation of Ltryptophan by selectively sulfonated gallium phthalocyanines: Singlet oxygen yields and effect of aggregation. Photochem. Photobiol. 1987 45,587

(35) Damoiseau, X.; Tfibel, F.; Hoebeke, M.; Fontaine-Aupart, M. P. Effect of aggregation on bacteriochlorin a triplet-state formation: A laser flash photolysis study. Photochem. Photobiol. 2002, 76, 480485

(36) Brewis, M.; Clarkson, G. J.; Helliwell, M.; Holder, A. M.; McKeown, N. B. The synthesis and glass-forming properties of phthalocyaninecontaining poly(aryl ether) dendrimers. Chem.-Eur. J. 2000, 6, 4630

(37) Zhu, Y. J ; Huang, J. D.; Jiang, X J ; Sun, J. C. Novel silicon phthalocyanines axially modified by morpholine: Synthesis, complexation with serum protein, and in vitro photodynamic activity. Inorg. Chem. Commun. 2006, 9, 473-477.

(38) Cauchon, N.; Tian, H. J.; Langlois, J.; La Madeleine, C.; Martin, S.; All, H.; Hunting, D.; van Lier, J. E. Structure-photodynamic activity relationships of substituted zinc trisulfophthalocyanines. Bioconjugate Chem. 2005, 16, 80-89.

(39) Niedre, M. J.; Secord, A. J.; Patterson, M. S.; Wilson, B. C. In vitro tests of the validity of singlet oxygen luminescence measurements as a dose metric in photodynamic therapy. Cancer Res. 2003, 63 , 7986-7994.

(40) Moan, J. On the diffusion length of singlet oxygen in cells and tissues. J. Photochem. Photobiol., B 1990, 6, 343-344.

(41) Moan, J.; Berg, K. The photodegradation of porphyrins in cells can be used to estimate the lifetime of singlet oxygen. Photochem. Photobiol. 1991, 53, 549-553.

(42) MacDonald, I. J.; Morgan, J.; Bellnier, D. A.; Paszkiewicz, G. M.; Whitaker, J. E.; Litchfield, D. J.; Dougherty, T. J. Subcellular localization patterns and their relationship to photodynamic activity of pyropheophorbide-a derivatives. Photochem. Photobiol. 1999, 70 , 789-797.

(43) Trivedi, N. S.; Wang, H. W.; Nieminen, A. L.; Oleinick, N. L.; Izatt, J. A. Quantitative analysis of Pc4 localization in mouse lymphoma (LY-R) cells via double-label confocal fluorescence microscopy. Photochem. Photobiol. 2000, 71, 634.
(44) Feofanov, A.; Sharonov, G.; Grichine, A.; Karmakova, T.; Pljutinskaya, A.; Lebedeva, V.; Ruziyev, R.; Yakubovskaya, R.; Mironov, A.; Refregier, M.; Maurizot, J. C.; Vigny, P. Comparative study of photodynamic properties of $13,15-N$-cycloimide derivatives of chlorin p6. Photochem. Photobiol. 2004, 79, 172

(45) Sharonov, G. V.; Karmakova, T. A.; Kassies, R.; Pljutinskaya, A. D.; Grin, M. A.; Refregiers, M.; Yakubovskaya, R. I.; Mironov, A F.; Maurizot, J. C.; Vigny, P.; Otto, C.; Feofanov, A. V. Cycloimide bacteriochlorin $\mathrm{p}$ derivatives: Photodynamic properties and cellular and tissue distribution. Free Radical Biol. Med. 2006, 40, 407.

(46) Martin, S.; Parton, R. G. Lipid droplets: A unified view of a dynamic organelle. Nat. Rev. Mol. Cell Biol. 2006, 7, 373-378.

(47) Murphy, D. J. The biogenesis and functions of lipid bodies in animals, plants and microorganisms. Prog. Lipid Res. 2001, 40, 325-438.

(48) Pol, A.; Martin, S.; Fernandez, M. A.; Ferguson, C.; Carozzi, A.; Luetterforst, R.; Enrich, C.; Parton, R. G. Dynamic and regulated association of caveolin with lipid bodies: Modulation of lipid body motility and function by a dominant negative mutant. Mol. Biol. Cell 2004, 15, 99-110.

(49) Parton, R. G. Caveolae and Caveolins. Curr. Opin. Cell Biol. 1996, $8,542-548$.

(50) Kirkham, M.; Parton, R. G. Clathrin-independent endocytosis: New insights into caveolae and non-caveolar lipid raft carriers. Biochim Biophys. Acta 2005, 1745, 273-286.

(51) Liu, W.; Jensen, T. J.; Fronczek, F. R.; Hammer, R. P.; Smith, K. M.; Vicente, M. G. H. Synthesis and cellular studies of nonaggregated water-soluble phthalocyanines. J. Med. Chem. 2005, 48, 1033-1041.

(52) Lin, W. Y.; Lawrence, D. S. A strategy for the construction of caged diols using a photolabile protecting group. J. Org. Chem. 2002, 67 2723-2726.

(53) Fasani, E.; Freccero, M.; Mella, M.; Albini, A. The role of SET in the deprotection of (thio)ketals under photosensitization by $\mathrm{p}$ acceptors. Tetrahedron 1997, 53, 2219.

(54) Chernyak, B. V.; Izyumov, D. S.; Lyamzaev, K. G.; Pashkovskaya, A. A.; Pletjushkina, O. Y.; Antonenko, Y. N.; Sakharov, D. V.; Wirtz K. W. A.; Skulachev, V. P. Production of reactive oxygen species in mitochondria of HeLa cells under oxidative stress. Biochim. Biophys. Acta 2006, 1757, 525-534.

(55) Sakharov, D. V.; Elstak, E. D. R.; Chernyak, B.; Wirtz, K. W. A. Prolonged lipid oxidation after photodynamic treatment. Study with oxidation-sensitive probe C11-BODIPY581/591. FEBS Lett. 2005, $579,1255-1260$

(56) Sakharov, D. V.; Bunschoten, A.; van Weelden, H.; Wirtz, K. W. A. Photodynamic treatment and $\mathrm{H} 2 \mathrm{O} 2$-induced oxidative stress result in different patterns of cellular protein oxidation. Eur. J. Biochem. 2003, 270, 4859-4865.

(57) Moan, J.; Berg, K.; Anholt, H.; Madslien, K. Sulfonated aluminium phthalocyanines as sensitizers for photochemotherapy. Effects of small light doses on localization, DYE fluorescence and photosensitivity in V79 cells. Int. J. Cancer 1994, 58, 865.

(58) Scheie, E.; Flåøen, A.; Moan, J.; Berg, K. Phylloerythrin: Mechanisms for cellular uptake and location, photosensitisation and spectroscopic evaluation. N. Z. Vet. J. 2002, 50, 104

(59) Oleinick, N. L.; Antunez, A. R.; Clay, M. E.; Rihter, B. D.; Kenney, M. E. New phthalocyanine photosensitizers for photodynamic therapy. Photochem. Photobiol. 1993, 57, 242.

(60) Scudiero, D. A.; Shoemaker, R. H.; Paull, K. D.; Monks, A.; Tierney, S.; Nofziger, T. H.; Currens, M. J.; Seniff, D.; Boyd, M. R. Evaluation of a soluble tetrazolium formazan assay for cell-growth and drug sensitivity in culture using human and other tumor-cell lines. Cancer Res. 1988, 48, 4827-4833.

(61) Smith, P. K.; Krohn, R. I.; Hermanson, G. T. Measurement of protein using bicinchoninic acid. Anal. Biochem. 1985, 150, 76.

JM061136W 